\title{
Formation of highly oxidized multifunctional compounds: autoxidation of peroxy radicals formed in the ozonolysis of alkenes - deduced from structure-product relationships
}

\author{
T. F. Mentel ${ }^{1}$, M. Springer ${ }^{1}$, M. Ehn ${ }^{1,2}$, E. Kleist ${ }^{3}$, I. Pullinen ${ }^{1}$, T. Kurtén ${ }^{4}$, M. Rissanen ${ }^{2}$, A. Wahner ${ }^{1}$, and J. Wildt ${ }^{3}$ \\ ${ }^{1}$ Institut für Energie- und Klimaforschung, IEK-8, Forschungszentrum Jülich, Jülich, Germany \\ ${ }^{2}$ Department of Physics, University of Helsinki, 00014 Helsinki, Finland \\ ${ }^{3}$ Institut für Bio- und Geowissenschaften, IBG-2, Forschungszentrum Jülich, Jülich, Germany \\ ${ }^{4}$ Department of Chemistry, University of Helsinki, 00014 Helsinki, Finland
}

Correspondence to: T. F. Mentel (t.mentel@fz-juelich.de)

Received: 22 November 2014 - Published in Atmos. Chem. Phys. Discuss.: 29 January 2015

Revised: 08 May 2015 - Accepted: 23 May 2015 - Published: 18 June 2015

\begin{abstract}
It has been postulated that secondary organic particulate matter plays a pivotal role in the early growth of newly formed particles in forest areas. The recently detected class of extremely low volatile organic compounds (ELVOC) provides the missing organic vapors and possibly contributes a significant fraction to atmospheric SOA (secondary organic aerosol). The sequential rearrangement of peroxy radicals and subsequent $\mathrm{O}_{2}$ addition results in ELVOC which are highly oxidized multifunctional molecules (HOM). Key for efficiency of such HOM in early particle growth is that their formation is induced by one attack of the oxidant (here $\mathrm{O}_{3}$ ), followed by an autoxidation process involving molecular oxygen. Similar mechanisms were recently observed and predicted by quantum mechanical calculations e.g., for isoprene. To assess the atmospheric importance and therewith the potential generality, it is crucial to understand the formation pathway of HOM.

To elucidate the formation path of HOM as well as necessary and sufficient structural prerequisites of their formation we studied homologous series of cycloalkenes in comparison to two monoterpenes. We were able to directly observe highly oxidized multifunctional peroxy radicals with 8 or $10 \mathrm{O}$ atoms by an Atmospheric Pressure interface High Resolution Time of Flight Mass Spectrometer (APi-TOFMS) equipped with a $\mathrm{NO}_{3}^{-}$-chemical ionization (CI) source. In the case of $\mathrm{O}_{3}$ acting as an oxidant, the starting peroxy radical is formed on the so-called vinylhydroperoxide path. HOM peroxy radicals and their termination reactions with
\end{abstract}

other peroxy radicals, including dimerization, allowed for analyzing the observed mass spectra and narrowing down the likely formation path. As consequence, we propose that HOM are multifunctional percarboxylic acids, with carbonyl, hydroperoxy, or hydroxy groups arising from the termination steps. We figured that aldehyde groups facilitate the initial rearrangement steps. In simple molecules like cycloalkenes, autoxidation was limited to both terminal $\mathrm{C}$ atoms and two further $\mathrm{C}$ atoms in the respective $\alpha$ positions. In more complex molecules containing tertiary $\mathrm{H}$ atoms or small, constrained rings, even higher oxidation degrees were possible, either by simple $\mathrm{H}$ shift of the tertiary $\mathrm{H}$ atom or by initialization of complex ring-opening reactions.

\section{Introduction}

The formation of new particles is an important process in the natural and anthropogenically influenced atmosphere (Kerminen et al., 2005; Kuang et al., 2009; Hamed et al., 2007; Kulmala et al., 2004a, 2013; Spracklen et al., 2010). While it seems clear now that sulfuric acid molecules, eventually in interaction with amines and ammonia, form the first nuclei (Bzdek et al., 2013; Berndt et al., 2005; Kuang et al., 2008; Sipälä et al., 2010; Vuollekoski et al., 2010; Zhao et al., 2011; Kirkby et al., 2011; Almeida et al., 2013), the mechanisms of growth of such nuclei has been under debate for a long time (Kulmala et al., 2004b, 2013; Kerminen et al., 
2010; Riccobono et al., 2012). Since new particle formation is often observed in forest regions with relatively clean air, the amount of sulfuric acid is insufficient to explain the observed growth and it has always been proposed that organic vapors should be involved in particle growth (Zhang et al., 2004; Metzger et al., 2010; Paasonen et al., 2010; Donahue et al., 2011; Riipinen et al., 2011, 2012; Ehn et al., 2012, 2014; Riccobono et al., 2014; Schobesberger et al., 2013; Kulmala et al., 2013). The organic vapors were supposed to have very low vapor pressures and it was estimated that such vapors could make up more than $50 \%$ of the organic fraction (Riipinen et al., 2011; Yli-Juuti et al., 2011). However, in the atmosphere, volatile organic compounds (VOC) are emitted mainly as hydrocarbons or with low degree of oxidation, otherwise they would not be volatile. Organic molecules with the required degree of oxidation and functionalization to exhibit sufficiently low vapor pressures very often require several oxidation steps to be formed from VOC in the gas phase by $\mathrm{OH}$ radicals. Stepwise oxidation by $\mathrm{OH}$ radicals makes the overall oxidation process slow and/or would lead to a high degree of diversification of products, as $\mathrm{OH}$ is not a very specific oxidation agent. Such sequential oxidation is not suited to produce high supersaturations of organic vapors required for growing molecular size critical nuclei.

New instrumentation, namely the atmospheric pressure interface time-of-flight mass spectrometer (APi-TOF-MS, Junninen et al., 2010) enabled the direct measurement of natural ions in the atmosphere. By applying APi-TOF-MS in Hyytiälä, a forestry station in southern Finland, Ehn et al. (2010) observed ions of organic compounds in mass ranges of 300-400 and 500-600 Da. They suggested at the time that these are highly oxidized organics, likely organic nitrates and their dimers. In a study in the Jülich Plant Atmosphere Chamber (JPAC) using APi-TOF-MS, Ehn et al. (2012) demonstrated that the organics observed in Hyytiälä mainly arise from $\alpha$-pinene ozonolysis; the mass spectrometric pattern derived for $\beta$-pinene and isoprene were different from that for $\alpha$-pinene. The JPAC is operated as continuously stirred flow reactor (Mentel et al., 2009) and the steady state can be conserved for an arbitrary duration. This allowed for long integration times and application of the low sensitivity but high resolution W mode of APi-TOF-MS. This way Ehn et al. (2012) determined that the compounds seen in the mass spectra in JPAC and Hyytiälä are highly oxidized $\mathrm{C}_{10}$ compounds clustered with $\mathrm{NO}_{3}^{-}$and the respective dimers, also clustered with $\mathrm{NO}_{3}^{-}$. The $\mathrm{C}_{10}$ compounds exhibit $\mathrm{O} / \mathrm{C}$ ratios close to one or larger and a number of $\mathrm{H}$ atoms similar to the reactant $\alpha$-pinene $\left(\mathrm{H}_{14}\right.$ or $\left.\mathrm{H}_{16}\right)$, resulting in molecular formulas $\mathrm{C}_{10} \mathrm{H}_{14,16} \mathrm{O}_{9-11}$. Similar organic molecules were observed independently in the CLOUD studies in clusters with sulfuric acid (Schobesberger et al., 2013).

The $\mathrm{C}_{10}$ compounds in question are highly oxidized multifunctional molecules (HOM, Ehn et al., 2012) and thus must have very low vapor pressures. They have been also called extremely low volatility organic compounds (ELVOC, Schobesberger et al., 2013, Ehn et al., 2014) in order to account for their role in the early stage of new particle formation and to distinguish them from other volatility classes such as low volatility organic compounds (LVOC), semi volatile organic compounds (SVOC), and intermediate volatility organic compounds (IVOC) which are discussed in atmospheric formation of secondary organic aerosol (SOA) (Donahue et al., 2012; Jimenez et al., 2009; Murphy et al., 2014). We focus here on the structure and chemistry of ELVOC and not so much on their atmospheric role in particle formation as extreme low volatility condensable organic vapors. We will therefore use the notation HOM (highly oxidized multifunctional molecules, Ehn et al., 2012) when referring to chemical structures and pathways and use the notation ELVOC, when referring to the impacts in the atmosphere.

By making use of the fact that ELVOC prefer to cluster with $\mathrm{NO}_{3}^{-}$, Ehn et al. (2014) applied $\mathrm{NO}_{3}^{-}$-CI-APi-TOFMS (Jokinen et al., 2012) and demonstrated that the formation of ELVOC is significant with a branching ratio of $7 \pm 3.5 \%$ of the turnover of $\alpha$-pinene with ozone. Moreover, it seems that endocyclic double bonds in monoterpenes like limonene are structural features that support ELVOC formation (Ehn et al., 2014; Jokinen et al., 2014). Further, it was suggested that a radical chain of peroxy radical formation and intramolecular $\mathrm{H}$ shifts could be the path to ELVOC formation, resulting in multiple hydroperoxides with increasing oxygen content in steps of $32 \mathrm{Da}$ (Ehn et al., 2014). H migration to peroxy radicals is known at elevated temperatures and for specific atmospheric radicals (Cox and Cole, 1985; Glowacki and Pilling, 2010; Jorand et al., 2003; Perrin et al., 1998) and the mechanism is commensurable with recent findings for the autoxidation of isoprene and related compounds (Crounse et al., 2012, 2013, 2011; Praplan et al., 2012) and with quantum-mechanical calculations, regarding the oxidation of monoterpenes (Vereecken and Francisco, 2012; Nguyen et al., 2010; Peeters et al., 2009; Vereecken et al., 2007). Jokinen et al. (2014) demonstrated HOM formation in detail for limonene, a monoterpene. The detailed chemistry of HOM formation from cyclohexene was elucidated by Rissanen et al. (2014). In this study, we investigated experimentally which structural and functional elements in organic molecules favor HOM formation initiated by ozonolysis.

In the studies by Ehn et al. $(2014,2012)$ HOM with an odd number of $\mathrm{H}$ atoms were detected, suggesting that highly oxidized peroxy radicals were observed. This observation was recently confirmed by Rissanen et al. (2014) and Jokinen et al. (2014). By increasing NO in the system, the peroxy radicals behaved as expected from classical atmospheric chemistry: their concentration decreased as did the concentration of dimer structures, and in turn organic nitrates increased (Ehn et al., 2014). As we will show in the following chapters, the peroxy radicals are indeed the pivotal point to understanding HOM formation. By comparing HOM formation 
Table 1. VOC investigated in this study, steady-state mixing ratio of VOC and $\mathrm{O}_{3}$ during the ozonolysis experiments, rate coefficient for the $\mathrm{VOC}+\mathrm{O}_{3}$ reactions at $298 \mathrm{~K}$.

\begin{tabular}{|c|c|c|c|c|c|c|}
\hline VOC & $\begin{array}{l}\text { Molecular } \\
\text { formula }\end{array}$ & $\begin{array}{r}\text { Molar mass } \\
{\left[\mathrm{g} \mathrm{mol}^{-1}\right]}\end{array}$ & $\begin{array}{r}\text { Purity } \\
{[\%]}\end{array}$ & $\begin{array}{r}{[\mathrm{VOC}]_{\mathrm{SS}}} \\
{[\mathrm{ppb}]}\end{array}$ & $\begin{array}{r}{\left[\mathrm{O}_{3}\right]_{\mathrm{SS}}} \\
{[\mathrm{ppb}]}\end{array}$ & $\begin{array}{l}k_{\mathrm{O} 3}^{\mathrm{e}}+\mathrm{VOC} \\
{\left[\mathrm{cm}^{3} \mathrm{~s}^{-1}\right]}\end{array}$ \\
\hline cyclopentene $^{\mathrm{b}}$ & $\mathrm{C}_{5} \mathrm{H}_{8}$ & 68.12 & 96 & 81 & 90 & $6.5 \times 10^{-16}$ \\
\hline cyclohexene $^{a}$ & $\mathrm{C}_{6} \mathrm{H}_{10}$ & 82.14 & $>99$ & 136 & 65 & $8 \times 10^{-17}$ \\
\hline 1-methyl-cyclohexene ${ }^{a}$ & $\mathrm{C}_{7} \mathrm{H}_{12}$ & 96.17 & 97 & 50 & 75 & $1.5 \times 10^{-16}$ \\
\hline 3-methyl-cyclohexene ${ }^{\mathrm{b}}$ & $\mathrm{C}_{7} \mathrm{H}_{12}$ & 96.17 & $>93$ & 26 & 84 & $5.5 \times 10^{-17}$ \\
\hline 4-methyl-cyclohexene $\mathrm{b}^{\mathrm{b}}$ & $\mathrm{C}_{7} \mathrm{H}_{12}$ & 96.17 & 98 & 88 & 70 & $7 \times 10^{-17}$ \\
\hline cycloheptene $^{\mathrm{a}}$ & $\mathrm{C}_{7} \mathrm{H}_{12}$ & 96.16 & 97 & 40 & 80 & $2.5 \times 10^{-16}$ \\
\hline 1-heptene ${ }^{\mathrm{a}}$ & $\mathrm{C}_{7} \mathrm{H}_{14}$ & 98.19 & 97 & 33 & 105 & $1.5 \times 10^{-17}$ \\
\hline (Z)-6-nonenal ${ }^{\mathrm{a}}$ & $\mathrm{C}_{9} \mathrm{H}_{16} \mathrm{O}$ & 140.22 & 92 & 44 & 90 & \\
\hline (Z)-6-nonen-(1)-ol' & $\mathrm{C}_{9} \mathrm{H}_{18} \mathrm{O}$ & 142.4 & $\geq 95$ & 1.4 & 80 & \\
\hline 5-hexen-2-one ${ }^{a}$ & $\mathrm{C}_{6} \mathrm{H}_{10} \mathrm{O}$ & 98.14 & 99 & 33 & 90 & \\
\hline$\alpha$-pinene ${ }^{\mathrm{a}}$ & $\mathrm{C}_{10} \mathrm{H}_{16}$ & 136.24 & $>99$ & 10 & 100 & $9 \times 10^{-17}$ \\
\hline$\Delta-3$-carene ${ }^{\mathrm{d}}$ & $\mathrm{C}_{10} \mathrm{H}_{16}$ & 136.24 & $\geq 98.5$ & 10 & 100 & $4 \times 10^{-17}$ \\
\hline
\end{tabular}

${ }^{\text {a }}$ Aldrich; ${ }^{\mathrm{b}}$ TCI $;{ }^{\mathrm{c}}$ SAFC; ${ }^{\mathrm{d}}$ Fluka; ${ }^{\mathrm{e}}$ NIST Gas Phase Kinetic Data Base (http://kinetics.nist.gov/kinetics/)

of selected model and representative compounds with specific structural properties we will deduce routes to highly oxidized multifunctional molecules, making use of established features of ozonolysis and termination reactions of peroxy radicals, together with the rearrangement of peroxy radicals by $\mathrm{H}$ shift from $\mathrm{C}--\mathrm{H}$ to $>\mathrm{COO}^{\circ}$ groups.

\section{Experimental}

All experiments were carried out in the Jülich Plant Atmospheric Chamber (JPAC). Details of the setup are described in Mentel et al. (2009) and Ehn et al. (2014). The largest chamber, with a volume of $1450 \mathrm{~L}$, was used in the experiments presented here, and it was operated as a continuously stirred flow reactor. Temperature $\left(T=17^{\circ} \mathrm{C}\right)$ and relative humidity $(\mathrm{RH}=60 \%)$ were held constant during the experiments. Two changes were implemented in the $1450 \mathrm{~L}$ reactor since Mentel et al. (2009): the whole UV lamp assembly is now placed in a $100 \mathrm{~mm}$ diameter quartz tube flanged in across the chamber from wall to wall, in order to reduce direct contact of the reaction mixture with the warm UV-lamp surface. On top of the Teflon floor of the chamber a glass floor was placed on $10 \mathrm{~mm}$ spacers in order to reduce fluorinated compounds and memory effects of $\mathrm{HNO}_{3}$ detected by Ehn et al. (2012). By pumping away the air in the space between Teflon plate and glass plate at a flow rate of $1.5 \mathrm{~L} \mathrm{~min}^{-1}$ diffusion of fluorinated compounds into the chamber was diminished.

Supply air was pumped through the chamber at a total flow of 30-35 $\mathrm{L} \mathrm{min}^{-1}$ resulting in a residence time of 40-50 min. The supply flow was split in two different lines for the reactants in order to prevent reactions in the supply lines. Ozone and water vapor was added to one of the air streams entering the reaction chamber, while the other inlet stream con- tained the volatile organic compound (VOC) of interest. The individual VOC were taken from diffusion sources which are described in Heiden et al. (2003). The hydrocarbons investigated in this study are listed in Table 1 together with their molecular mass, purity and supply information. The steady-state concentrations of the VOC during the experiments are given in Table 1. Independent of the VOC added to the chamber, the ozone flow into the reaction chamber was held constant. As a consequence, the steady-state $\mathrm{O}_{3}$ concentrations varied depending on the reactivity of added hydrocarbons with respect to $\mathrm{O}_{3}$ as given in Table 1. All experiments were performed under low $\mathrm{NO}(\mathrm{NO}<30 \mathrm{ppt})$ and low $\mathrm{NO}_{2}\left(\mathrm{NO}_{2}<300 \mathrm{ppt}\right)$ conditions.

The central analytical instrument was an Atmospheric Pressure interface High Resolution Time of Flight Mass Spectrometer (APi-TOF-MS, Aerodyne Research Inc. \& Tofwerk AG; Junninen et al., 2010). The APi-TOF-MS was equipped with a $\mathrm{NO}_{3}^{-}$-chemical ionization (CI) source (Eisele and Tanner, 1993; Jokinen et al., 2012; A70 CI-inlet, Airmodus Ltd) for the detection of highly oxidized organic compounds. The reagent ion ${ }^{15} \mathrm{NO}_{3}^{-}$for the CI was generated by using labeled $\mathrm{H}^{15} \mathrm{NO}_{3}\left(\sim 10 \mathrm{~N}\right.$ in $\mathrm{H}_{2} \mathrm{O}, 98$ atom\% ${ }^{15} \mathrm{~N}$, Aldrich Chemistry), ionized by an in-line ${ }^{241} \mathrm{Am}$ foil. As was shown by Ehn et al. (2012) the anion $\mathrm{NO}_{3}^{-}$is able to form a cluster with the expected highly oxidized organic compounds. The labeling with ${ }^{15} \mathrm{NO}_{3}^{-}$enables to distinguish between ${ }^{15} \mathrm{~N}$ from the reagent and ${ }^{14} \mathrm{~N}$ that has been incorporated into the sample molecules, e.g., through reactions with ${ }^{14} \mathrm{NO}$ in the reaction chamber.

The sampling flow from the reaction chamber into the CI source was $10 \mathrm{~L} \mathrm{~min}^{-1}$. The flow into the APi-TOF-MS was thereafter reduced to $0.8 \mathrm{~L} \mathrm{~min}^{-1}$ by passing a critical orifice. Differential pumping by a scroll pump and a threestage turbo pump sequentially decreased the pressure from 


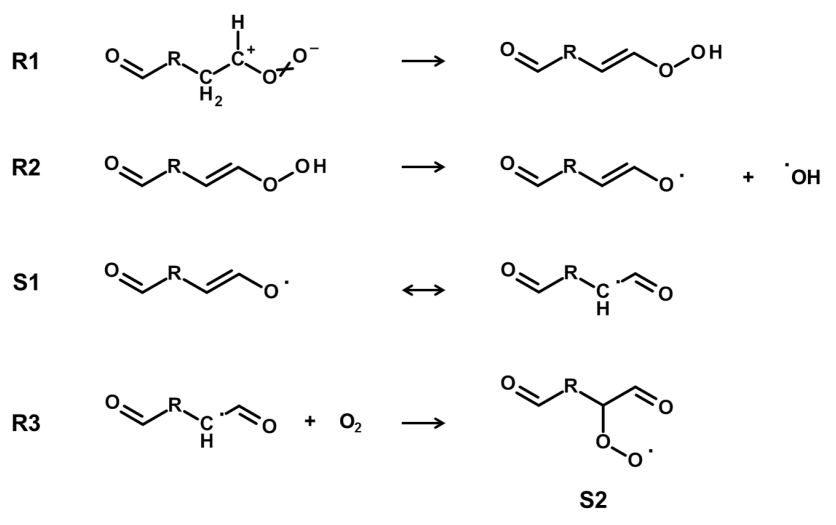

Sequence 1. Vinylhydroperoxide path in ozonolysis.

$10^{3}$ mbar in the $\mathrm{CI}$ region to $10^{-6} \mathrm{mbar}$ in the time-of-flight region. Once the ions are sampled into the APi-TOF region, they are guided by segmented quadrupole mass filters and electrical lenses in the TOF extraction region. Collisions between ions and gas molecules will take place, but the energies are tuned low enough that only weakly bound clusters (e.g., water clusters) will fragment. After extraction into the TOF the ions are separated by their different flight times depending on their mass to charge ratio.

The sensitivity of the APi-TOF operated as $\mathrm{NO}_{3}^{-}$-CIMS is discussed in Ehn et al. (2014). We have indication that once a certain degree of functionalization is achieved (two $\mathrm{OH}$ or $\mathrm{OOH}$ groups in addition to two carbonyl groups) the sensitivity is fairly the same for all HOM species (Mikael Ehn, Theo Kurten, personal communication). HOM with six or fewer $\mathrm{C}$ atoms and fewer than six atoms were not detected. However, we found hints that we may be able to detect HOM with less than six $\mathrm{O}$ atoms in molecules with seven or more $\mathrm{C}$ atoms. Thus, the general polarizability of a molecule may play a role besides directed interactions of functional groups with the $\mathrm{NO}_{3}^{-}$ion.

To control whether or not peaks in the APi-TOF mass spectra originated from oxidation of the added VOC, blank experiments without VOC addition were performed. Ozone was left in the chamber to simulate cases of peaks originating from ozonolysis of impurities. Some of the peaks in the mass spectra were abundant also in absence of VOC and likely arise from fluorinated contaminants. All peaks observable without VOC addition were rejected from interpretation.

Ozonolysis of alkenes in the dark produces $\mathrm{OH}$ radicals. We did not use $\mathrm{OH}$ scavenger in most of our experiments. However, in some control experiments $\mathrm{OH}$ produced during alkene ozonolysis was scavenged by adding $\sim 40 \mathrm{ppm}$ carbon monoxide (CO). Addition of $\mathrm{CO}$ did not change the majority of the patterns in the mass spectra indicating that ozonolysis was indeed the major pathway of HOM formation under the experimental conditions. Nevertheless, $\mathrm{CO}$ addition changed the abundance of certain HOM. This was used for to separate $\mathrm{OH}$ reactions as origin for these HOM.

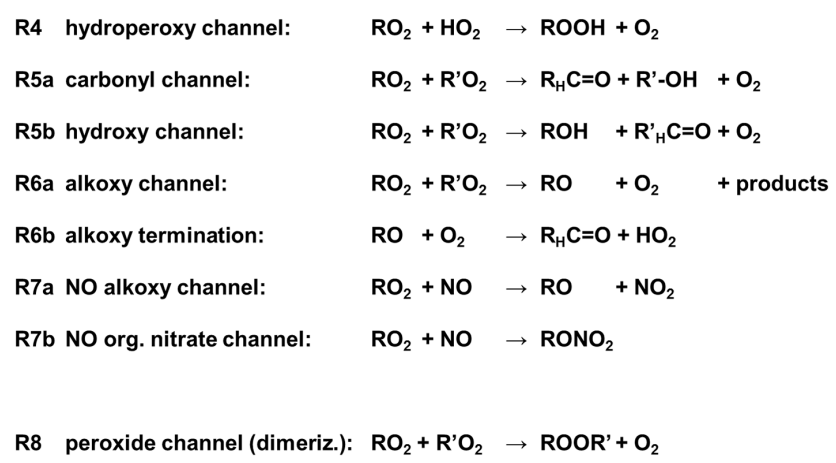

Sequence 2. General $\mathrm{RO}_{2}$ reactions.

\section{Methods}

The goal of this section is to derive an a priori expectation scheme for formation of highly oxidized molecules from ozonolysis of VOC with endocyclic double bonds, and to predict which intermediates and termination products should be formed according to classical understanding and recent mechanistic developments. As we will show, comparison of the expectations to the observed mass spectra (positive hits) will make it easier to identify and organize the observations. Of course the scheme was developed a posteriori but presenting it beforehand will help the reader to follow the argumentation.

Under our experimental conditions the ozonolysis is the major pathway of alkene oxidation. In the case of alkenes with endocyclic double bonds, ozonolysis leads to ring opening with a Criegee intermediate at one end of the carbon chain and a carbonyl group on the other end. The Criegee intermediate further reacts in several ways. One of these is the so-called vinylhydroperoxide pathway (Reactions R1-R3, see Sequence 1). The decomposition of the vinylhydroperoxides (Reaction R2) leads to a radical with mesomeric structures (S1, see Sequence 1). Importantly here, the peroxy radical $\mathrm{S} 2$ is formed by subsequent $\mathrm{O}_{2}$ addition to the oxo-alkyl mesomeric structure (Reaction R3) (cf. reviews of Johnson and Marston, 2008; Vereecken and Francisco, 2012).

Peroxy radical S2 is the starting point of the following considerations. As shown in Sequence 2 in general, the reaction chain can be terminated by the known reactions of the peroxy radicals (denoted as $\mathrm{RO}_{2}$ ) with $\mathrm{HO}_{2}$ (Reaction R4), with other peroxy radicals (Reactions R5, R8), or with NO (Reaction R7b) leading to termination products with hydroperoxy, carbonyl, or hydroxy groups, alkylperoxides, or organic nitrates. The chain can also be continued by peroxyperoxy (Reaction R6a) and peroxy-NO (Reaction R7a) reactions via alkoxy intermediates. The latter form carbonyl compounds (Reaction R6b) or fragment into smaller units (e.g., Vereecken and Francisco, 2012). In addition, alkoxy radicals can undergo isomerization reactions like the $\mathrm{H}$ shift with subsequent $\mathrm{O}_{2}$ addition (see Sequence 3, Vereecken and 


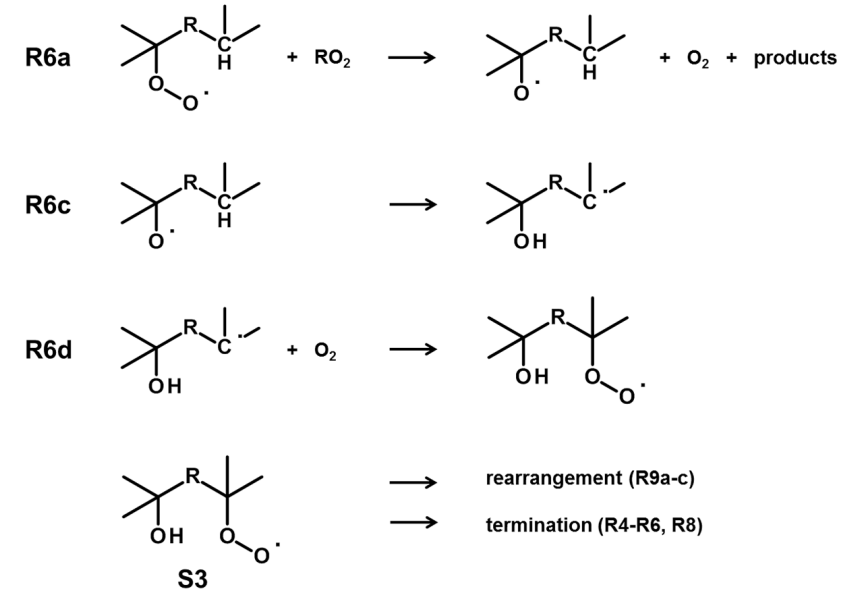

Sequence 3. Hydroxy-peroxy path via alkoxy channel.

Francisco, 2012; Vereecken and Peeters, 2010). Note that the peroxy functionality is recycled in Sequence 3, generating $\mathrm{OH}$-functionalized peroxy radicals. Hydroxy-peroxy radicals can be terminated in the usual way (Sequence 2). All these principle pathways are either known (e.g., FinlaysonPitts and Pitts Jr., 2000) or have been recently discussed, based on either calculations (e.g., Vereecken and Francisco, 2012) and/or observations for $\mathrm{C}_{5}$ compounds (e.g., Crounse et al., 2013).

We will also allow for $\mathrm{H}$ shifts from $\mathrm{C}-\mathrm{H}$ bonds also in peroxy radicals (Sequence 4), leading to $-\mathrm{OOH}$ functionalized peroxy radicals (Crounse et al., 2013; Vereecken et al., 2007). This rearrangement was known for processes at elevated temperatures (Cox and Cole, 1985; Glowacki and Pilling, 2010; Jorand et al., 2003; Perrin et al., 1998), but has not been considered as important in gas-phase atmospheric chemistry until recently. In addition, intramolecular termination R9c can occur, an $\mathrm{H}$ shift from the $\mathrm{C}-\mathrm{H}$ bond that carries the hydroperoxy group, leading to a split off of $\mathrm{OH}$ and a carbonyl termination product (Crounse et al., 2013; Rissanen et al., 2014). Sequence 4 explains the mass increase in steps of $32 \mathrm{Th}$ in the type of HOM observed by Ehn et al. (2012, 2014) and investigated here. Since it requires only a single attack by the oxidant $\mathrm{O}_{3}$ and then proceeds by itself under involvement of only molecular oxygen, it can be interpreted as an autoxidation process.

We will apply the known steps (Reactions R4-R6, Sequence 2) and rearrangement and autoxidation of peroxy radicals (Sequences 4 and 3) to construct a pathway to form atmospheric HOM which is in accordance with both, our mass spectral observations and experimental findings as well as the quantum mechanical calculations by Rissanen et al. (2014). Since we were working at low $\mathrm{NO}_{x}(<300 \mathrm{ppt})$ and under conditions of negligible $\mathrm{NO}_{2}$ photolysis we will neglect the NO pathways (Reaction R7, Sequence 2).

In this study we will focus on such pathways where the peroxy radicals and their termination products retain the

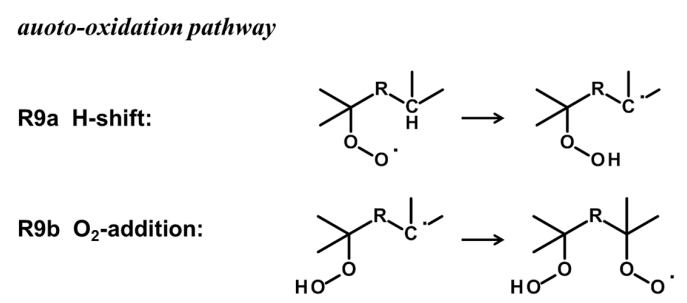

intramolecular termination

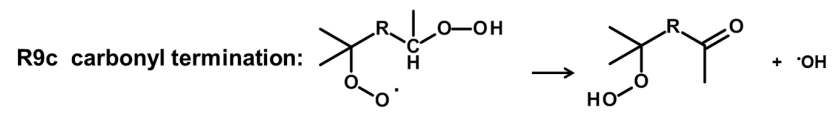

Sequence 4. Peroxy path.

carbon number of the reactants. These are the majority of the observed products. In addition, we will consider their dimers with twice the number of $\mathrm{C}$ atoms (Reaction $\mathrm{R} 8$, Sequence 2).

As we will show, most of the observed HOM arise from the straight peroxy autoxidation path (Sequence 4), which we will denote as peroxy path. However, often a minor fraction of products arises from Sequence 3, which we will call the hydroxy-peroxy path. Peroxy radicals arising from the hydroxy-peroxy path are $\mathrm{OH}$ substituted and contain an odd number of O atoms (like S3 in Sequence 3). The hydroxyperoxy radical can carry on the autoxidation (Sequence 4) and terminate in usual ways (Reactions R4-R6 and Reaction R8 in Sequence 2).

Applying the principles outlined above to the example of cyclopentene, we may expect from the peroxy path the type of species in Table 2a; possible intermediates and products from hydroxy-peroxy path are shown in Table $2 b$. According to the vinylhydroperoxide path the starting peroxy radical in the series (upper left corner of Table $2 \mathrm{a}$ ) is a $\mathrm{C}_{5}$ chain with aldehyde functions on both ends. In addition, a peroxy radical function is located at the $\mathrm{C}$ atom in $\alpha$-position to one of the aldehyde groups: $\mathrm{S} 2$ with $R=\left(\mathrm{CH}_{2}\right)_{2}$ (see Sequence 1).

Radical S2 is the starting point for either further $\mathrm{H}$ shift $/ \mathrm{O}_{2}$ addition (Table 2a, down the first column) or termination products (along the line). The scheme does not explain the relative importance of the pathways, only that they could be a priori possible. In reality, the abundances of stable termination products and postulated peroxy radicals are the result of detailed local molecular structure and a complex formation and destruction scheme as discussed below (individual lifetimes, cf. Rissanen et al., 2014). Moreover, our detection method may require a certain minimum degree of oxidation of the analyte molecules before they can be detected as nitrate clusters. The parent peroxy radicals with molecular mass $m$ and their termination products form a repeated pattern $m-17$ (carbonyl), $m-15$ (hydroxy), $m, m+1$ (hydroperoxy) in the mass spectra. This is indicated in the second line of Table 2a. 
Table 2. (a) Possible peroxy radicals from cyclopentene and products of their reactions with peroxy radicals (cf. Sequence 2). (b) Analogous scheme for the hydroxy-peroxy path. The first peroxy radical in (b) arise from the first peroxy radical in (a) by reaction with another peroxy radical (or NO).

\begin{tabular}{|c|c|c|c|c|}
\hline & Peroxy radical & Carbonyl & Hydroxy & Hydroperoxy \\
\hline (a) & $m$ & $m-17$ & $m-15$ & $m+1$ \\
\hline \multirow{8}{*}{$\downarrow$ autoxidation } & $\mathrm{C}_{5} \mathrm{H}_{7} \mathrm{O}_{4}$ & $\mathrm{C}_{5} \mathrm{H}_{6} \mathrm{O}_{3}$ & $\mathrm{C}_{5} \mathrm{H}_{8} \mathrm{O}_{3}$ & $\mathrm{C}_{5} \mathrm{H}_{8} \mathrm{O}_{4}$ \\
\hline & $131 \mathrm{Da}$ & $114 \mathrm{Da}$ & $116 \mathrm{Da}$ & $132 \mathrm{Da}$ \\
\hline & $\mathrm{C}_{5} \mathrm{H}_{7} \mathrm{O}_{6}$ & $\mathrm{C}_{5} \mathrm{H}_{6} \mathrm{O}_{5}$ & $\mathrm{C}_{5} \mathrm{H}_{8} \mathrm{O}_{5}$ & $\mathrm{C}_{5} \mathrm{H}_{8} \mathrm{O}_{6}$ \\
\hline & $163 \mathrm{Da}$ & $146 \mathrm{Da}$ & $148 \mathrm{Da}$ & $164 \mathrm{Da}$ \\
\hline & $\mathrm{C}_{5} \mathrm{H}_{7} \mathrm{O}_{8}$ & $\mathrm{C}_{5} \mathrm{H}_{6} \mathrm{O}_{7}$ & $\mathrm{C}_{5} \mathrm{H}_{8} \mathrm{O}_{7}$ & $\mathrm{C}_{5} \mathrm{H}_{8} \mathrm{O}_{8}$ \\
\hline & $195 \mathrm{Da}$ & $178 \mathrm{Da}$ & $180 \mathrm{Da}$ & $196 \mathrm{Da}$ \\
\hline & $\mathrm{C}_{5} \mathrm{H}_{7} \mathrm{O}_{10}$ & $\mathrm{C}_{5} \mathrm{H}_{6} \mathrm{O}_{9}$ & $\mathrm{C}_{5} \mathrm{H}_{8} \mathrm{O}_{9}$ & $\mathrm{C}_{5} \mathrm{H}_{8} \mathrm{O}_{10}$ \\
\hline & $227 \mathrm{Da}$ & $210 \mathrm{Da}$ & $212 \mathrm{Da}$ & $228 \mathrm{Da}$ \\
\hline & & \multicolumn{3}{|c|}{ termination $\rightarrow$} \\
\hline (b) & $m$ & $m-17$ & $m-15$ & $m+1$ \\
\hline \multirow{7}{*}{$\begin{array}{l}\downarrow \\
\text { autoxidation } \\
\text { after Sequence } 3\end{array}$} & $\mathrm{C}_{5} \mathrm{H}_{7} \mathrm{O}_{5}$ & $\mathrm{C}_{5} \mathrm{H}_{6} \mathrm{O}_{4}$ & $\mathrm{C}_{5} \mathrm{H}_{8} \mathrm{O}_{4}$ & $\mathrm{C}_{5} \mathrm{H}_{8} \mathrm{O}_{5}$ \\
\hline & $147 \mathrm{Da}$ & $130 \mathrm{Da}$ & $132 \mathrm{Da}$ & $148 \mathrm{Da}$ \\
\hline & $\mathrm{C}_{5} \mathrm{H}_{7} \mathrm{O}_{7}$ & $\mathrm{C}_{5} \mathrm{H}_{6} \mathrm{O}_{6}$ & $\mathrm{C}_{5} \mathrm{H}_{8} \mathrm{O}_{6}$ & $\mathrm{C}_{5} \mathrm{H}_{8} \mathrm{O}_{7}$ \\
\hline & $179 \mathrm{Da}$ & $162 \mathrm{Da}$ & $164 \mathrm{Da}$ & $180 \mathrm{Da}$ \\
\hline & $\mathrm{C}_{5} \mathrm{H}_{7} \mathrm{O}_{9}$ & $\mathrm{C}_{5} \mathrm{H}_{6} \mathrm{O}_{8}$ & $\mathrm{C}_{5} \mathrm{H}_{8} \mathrm{O}_{8}$ & $\mathrm{C}_{5} \mathrm{H}_{8} \mathrm{O}_{9}$ \\
\hline & $211 \mathrm{Da}$ & $194 \mathrm{Da}$ & $196 \mathrm{Da}$ & $212 \mathrm{Da}$ \\
\hline & & \multicolumn{3}{|c|}{ termination $\rightarrow$} \\
\hline
\end{tabular}

The first entrée in Table $2 \mathrm{~b}$ is a hydroxy-peroxy radical of type S3 which is formed by Sequence 3 from the starting intermediate $\mathrm{S} 2$ in Table $2 \mathrm{a}$. The hydroxy-peroxy radicals noted in the first column of Table $2 \mathrm{~b}$ can be either formed by Sequence 3 from the corresponding peroxy radicals noted in the first column of Table $2 \mathrm{a}$ or in increments of $\mathrm{O}_{2}$ by $\mathrm{H}$ shift $/ \mathrm{O}_{2}$ addition (Sequence 4 ) of the previous hydroxyperoxy radical.

It is evident from Table 2 that both peroxy and hydroxyperoxy pathways generate progressions in the mass spectra with distance $32 \mathrm{Da}(2 \times \mathrm{O})$. However, the two progressions are shifted by 16 (the $\mathrm{O}$ of the hydroxy group in the hydroxyperoxy radical) with respect to each other. This can lead to isobaric overlap of hydroperoxides $(m+1)$ from the peroxide $m$ and hydroxy termination products from the corresponding hydroxy-peroxide at $m+16(m+16-15$, cf. column 4 in Table $2 \mathrm{a}$ and column 3 in Table $2 \mathrm{~b}$ ).

We investigated several compounds to detect structural prerequisites of the formation of HOM. The cyclic alkenes cyclopentene, cyclohexene, and cycloheptene were used to study the impact of chain length on HOM formation. 1methyl-cyclohexene was used to study possible impacts of methyl-substitution of the double bond, with structural similarity to $\alpha$-pinene. In 3-methyl-cyclohexene and 4-methylcyclohexene, the methyl substituent is moving away from the endocyclic double bond, and they provide branched $\mathrm{C}_{7}$ variations of cycloheptene.

Finally, we studied the formation of HOM from the functionalized linear alkenes (Z)-6-nonenal, (Z)-6-nonenol, (5)hexen-2-one, and 1-heptene. These compounds were chosen because during ozonolysis they should produce a peroxy radical function located in $\alpha$-position to the forming aldehyde group (similar to S2, Sequence 1), but carry a different or none functional group at the other, the terminal or $\omega$ $\mathrm{C}$ atom, end of the chain. The reason was to study the impact of a functionalization on atmospheric HOM formation. Two monoterpenes, $\alpha$-pinene and $\Delta$-3-carene, both abundant in nature, serve as test cases for atmospherically relevant, complex bicyclic molecules. $\alpha$-pinene and $\Delta$-3-carene carry tertiary $\mathrm{H}$ atoms, as do 3-methyl-cyclohexene and 4-methylcyclohexene.

\section{Results}

Closed-shell HOM and their peroxy intermediates were detected as clusters with one ${ }^{15} \mathrm{NO}_{3}^{-}$ion attached (Ehn et al., 2012 , 2014). Note that the postulated peroxy radicals have odd molecular masses because of the missing $\mathrm{H}$ atom, but due to the use of ${ }^{15} \mathrm{~N}$ labeled nitric acid to generate ${ }^{15} \mathrm{NO}_{3}^{-}$ as reagent ion they will be detected as ${ }^{15} \mathrm{NO}_{3}^{-}$-cluster at even 
Table 3. Observation of HOM formation as function of compound and functionalization.

\begin{tabular}{|c|c|c|c|}
\hline Compound & Formula & HOM products & $\omega$-Terminal group ${ }^{\mathrm{a}}$ \\
\hline \multicolumn{4}{|c|}{ Cyclic alkenes } \\
\hline cyclopentene & $\mathrm{C}_{5} \mathrm{H}_{8}$ & yes & aldehyde \\
\hline cyclohexene & $\mathrm{C}_{6} \mathrm{H}_{10}$ & yes & aldehyde \\
\hline cycloheptene & $\mathrm{C}_{7} \mathrm{H}_{12}$ & yes & aldehyde \\
\hline 1-methyl-cyclohexene & $\mathrm{C}_{7} \mathrm{H}_{12}$ & yes & ketone/aldehyde \\
\hline 3-methyl-cyclohexene & $\mathrm{C}_{7} \mathrm{H}_{12}$ & yes & aldehyde \\
\hline 4-methyl-cylohexene & $\mathrm{C}_{7} \mathrm{H}_{12}$ & yes & aldehyde \\
\hline \multicolumn{4}{|c|}{ Linear alkene } \\
\hline 1-heptene & $\mathrm{C}_{7} \mathrm{H}_{14}$ & no & methyl \\
\hline \multicolumn{4}{|c|}{ Linear alkenes with additional functional group } \\
\hline (Z)-6-nonenal & $\mathrm{C}_{9} \mathrm{H}_{16} \mathrm{O}$ & yes & aldehyde \\
\hline (Z)-6-nonenol & $\mathrm{C}_{9} \mathrm{H}_{17} \mathrm{OH}$ & no & alcohol \\
\hline 5-hexen-2-on & $\mathrm{C}_{6} \mathrm{H}_{10} \mathrm{O}$ & no & ketone \\
\hline \multicolumn{4}{|c|}{ Monoterpenes } \\
\hline$\alpha$-pinene & $\mathrm{C}_{10} \mathrm{H}_{16}$ & yes & ketone/aldehyde \\
\hline$\Delta-3$-carene & $\mathrm{C}_{10} \mathrm{H}_{16}$ & yes & ketone/aldehyde \\
\hline
\end{tabular}

a at the opposite end to the oxoic radical groups in Fig. 3

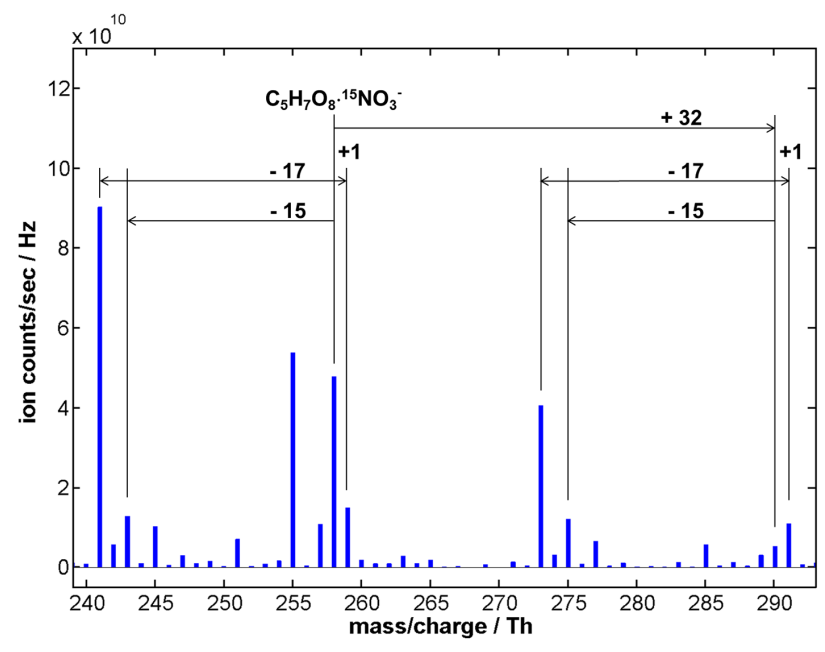

Figure 1. Spectrum of ozonolysis products of cyclopentene. The most abundant peroxy radical $\mathrm{C}_{5} \mathrm{H}_{7} \mathrm{O}_{8} \cdot{ }^{15} \mathrm{NO}_{3}^{-}$and its termination products are marked as well as the next higher peroxy radical $(+32 \mathrm{Th})$ and termination products. The $m / z$ differences in [Th] are indicated.

masses. In the same sense, all closed-shell molecules will be detected as ${ }^{15} \mathrm{NO}_{3}^{-}$-clusters at odd masses.

Figure 1 shows a typical mass spectrum observed for cyclopentene ozonolysis in the range between 240 and $280 \mathrm{Th}$, which is where the nitrate clusters of $\mathrm{C}_{5}-\mathrm{HOM}$ are expected. It shows that we indeed observe the set of termination products as developed in Sect. 3. In addition, we found

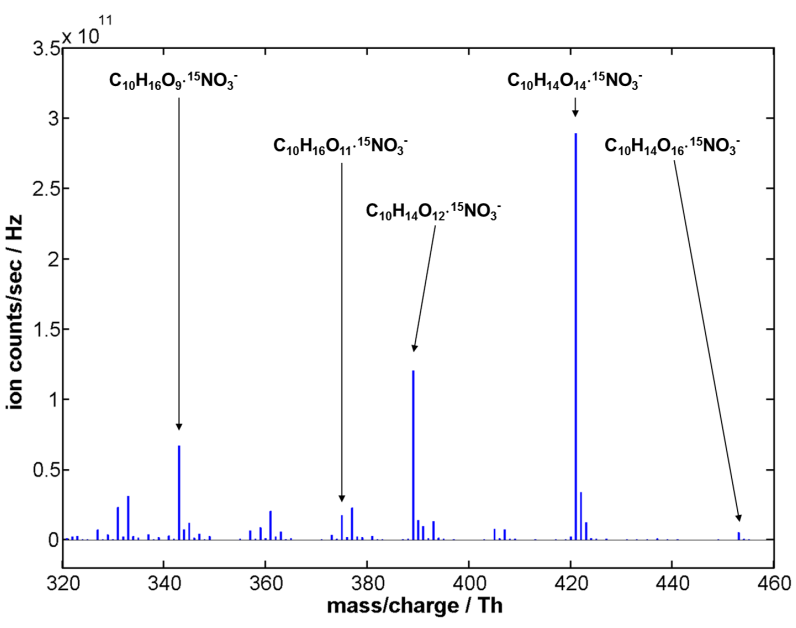

Figure 2. Spectrum of ozonolysis products of cyclopentene with dimer character. The detected elemental compositions are indicated (cf. Sect. 5.4).

a peak at $258 \mathrm{Th}$ to which we attributed the molecular formula $\mathrm{C}_{5} \mathrm{H}_{7} \mathrm{O}_{8} \cdot \mathrm{NO}_{3}^{-}$. This cluster has an odd number of $\mathrm{H}$ atoms indicating that the organic moiety is not a closedshell molecule. As we will show in the following chapter, this indeed is the peroxy radical. The corresponding termination products are indicated by their mass difference to the peroxy radical at $m=258 \mathrm{Th}$, as introduced in Sect. 3. The signal at $273 \mathrm{Th}$ is the carbonyl termination product from the 


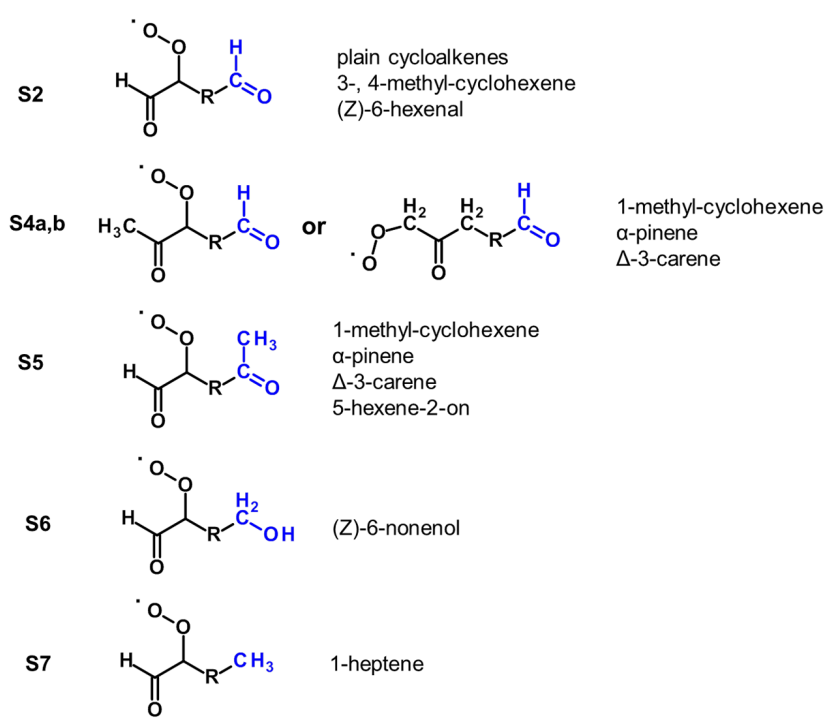

Figure 3. Peroxy radicals of the investigated VOC as expected from the vinylhydroperoxide path. Position of the peroxy group and functionality at the $\omega$-terminal end.

next progression shifted by $32 \mathrm{Th}$. The peak at $255 \mathrm{Th}$ is a cluster with a perfluorinated acid (chamber artefact).

Figure 2 shows the same mass spectrum in the region of dimer structures. The two largest peaks at 421 and $389 \mathrm{Th}$ have organic moieties with molecular formulas $\mathrm{C}_{10} \mathrm{H}_{14} \mathrm{O}_{14}$ and $\mathrm{C}_{10} \mathrm{H}_{14} \mathrm{O}_{12}$, which we will attribute to peroxides formed by recombination of peroxy radicals. The molecular formulas assigned to the peaks at 343 and $375 \mathrm{Th}$ contain 16 $\mathrm{H}$ atoms and odd number of oxygen $\left(\mathrm{C}_{10} \mathrm{H}_{16} \mathrm{O}_{9}, \mathrm{C}_{10} \mathrm{H}_{16} \mathrm{O}_{11}\right)$ and the compounds are obviously formed on a different formation path. As we did not scavenge $\mathrm{OH}$ radicals also formed in the vinylhydroperoxide path, oxidation by $\mathrm{OH}$ may be involved in the formation of these compounds.

Similar mass spectrometric patterns were observed for all investigated compounds that form HOM, and Table 3 gives the overview which of the compounds formed HOM in our ozonolysis experiments. In Table 3, we also list the functionalization at the $\omega$-C atom, the opposite end of the initial peroxy radical, as explained by structures $\mathrm{S} 2, \mathrm{~S} 4 \mathrm{a}, \mathrm{S} 4 \mathrm{~b}$, and S5-S7 in Fig. 3. In the case of methyl-substituted double bonds, the symmetry is broken and the initial peroxy radical can be either formed at the unsubstituted site of the double bond, then the $\omega$-terminal group is an acetyl group (S5) or at the substituted site $(\mathrm{S} 4 \mathrm{a}, \mathrm{b})$ then the $\omega$-terminal group is an aldehyde. In the case of the linear alkenes, we consider only the product with the longer $\mathrm{C}$ chain after ozonolysis of the double bond. The peroxy group resides in $\alpha$-position to the remaining $\mathrm{C}$ atom of the double bond leaving the $\omega$ terminal group to whatever was at the other end of the parent molecule.

Efficient formation of highly oxidized molecules was found for the ozonolysis of all endocyclic alkenes, includ-
Table 4. HOM observed during ozonolysis of cyclopentene. The second header line shows at which molar masses the termination products are expected relative to the peroxy radical with molar mass $m$ (unit masses). Filled cells indicate that these compounds were detected with given elemental composition and relative intensity (second line in the same cell). Relative intensities were normalized to the largest HOM signal. The third line in the cell gives the molar mass $[\mathrm{Da}]$ in unit mass resolution and the precise $m / z$ [Th] at which the molecule was detected as cluster with ${ }^{15} \mathrm{NO}_{3}^{-}$.

\begin{tabular}{llll}
\hline Peroxy radical & Carbonyl & Hydroxy & Hydroperoxy \\
\hline$m$ & $m-17$ & $m-15$ & $m+1$ \\
\hline $\mathrm{C}_{5} \mathrm{H}_{7} \mathrm{O}_{8}$ & $\mathrm{C}_{5} \mathrm{H}_{6} \mathrm{O}_{7}$ & $\mathrm{C}_{5} \mathrm{H}_{8} \mathrm{O}_{7}$ & $\mathrm{C}_{5} \mathrm{H}_{8} \mathrm{O}_{8}$ \\
$54 \%$ & $100 \%$ & $14 \%$ & $19 \%$ \\
$195 / 257.9995$ & $178 / 240.996$ & $180 / 243.0124$ & $196 / 259.0073$ \\
\hline $\mathrm{C}_{5} \mathrm{H}_{7} \mathrm{O}_{9}^{\mathrm{a}}$ & & $\mathrm{C}_{5} \mathrm{H}_{8} \mathrm{O}_{8}$ & \\
$1 \%$ & & $19 \%{ }^{\mathrm{b}}$ & \\
$211 / 273.9944$ & & $196 / 259.0073$ & \\
\hline $\mathrm{C}_{5} \mathrm{H}_{7} \mathrm{O}_{10}$ & $\mathrm{C}_{5} \mathrm{H}_{6} \mathrm{O}_{9}$ & $\mathrm{C}_{5} \mathrm{H}_{8} \mathrm{O}_{9}$ & \\
$6 \%$ & $43 \%$ & $11 \%$ & \\
$227 / 289.9893$ & $210 / 272.9866$ & $212 / 275.0022$ & \\
\hline
\end{tabular}

a hydroxy-peroxy path Sequence 3

${ }^{b} \mathrm{C}_{5} \mathrm{H}_{7} \mathrm{O}_{8}+\mathrm{HO}_{2} \rightarrow \mathrm{C}_{5} \mathrm{H}_{8} \mathrm{O}_{8}$ or $\mathrm{C}_{5} \mathrm{H}_{7} \mathrm{O}_{9}+\mathrm{RO}_{2} \rightarrow \mathrm{C}_{5} \mathrm{H}_{8} \mathrm{O}_{8}$

Table 5. HOM observed during ozonolysis of cyclohexene. The second header line shows at which molar masses the termination products are expected relative to the peroxy radical with molar mass $m$ (unit masses). Filled cells indicate that these compounds were detected with given elemental composition and relative intensity (second line in the same cell). Relative intensities were normalized to the largest HOM signal. The third line in the cell gives the molar mass $[\mathrm{Da}]$ in unit mass resolution and the precise $m / z$ [Th] at which the molecule was detected as cluster with ${ }^{15} \mathrm{NO}_{3}^{-}$.

\begin{tabular}{llll}
\hline Peroxy radical & Carbonyl & Hydroxy & Hydroperoxy \\
\hline$m$ & $m-17$ & $m-15$ & $m+1$ \\
\hline $\mathrm{C}_{6} \mathrm{H}_{9} \mathrm{O}_{8}$ & $\mathrm{C}_{6} \mathrm{H}_{8} \mathrm{O}_{7}$ & $\mathrm{C}_{6} \mathrm{H}_{10} \mathrm{O}_{7}$ & $\mathrm{C}_{6} \mathrm{H}_{10} \mathrm{O}_{8}$ \\
$7 \%$ & $24 \%$ & $1 \%$ & $5 \%$ \\
$209 / 272.01453$ & $192 / 255.01270$ & $194 / 257.02523$ & $210 / 273.0230$ \\
\hline & $\mathrm{C}_{6} \mathrm{H}_{8} \mathrm{O}_{8}^{\mathrm{a}}$ & & \\
& $14 \%$ & & \\
& $208 / 271.00724$ & & $\mathrm{C}_{6} \mathrm{H}_{10} \mathrm{O}_{10}$ \\
& $\mathrm{C}_{6} \mathrm{H}_{8} \mathrm{O}_{9}$ & & $<1 \%$ \\
$\mathrm{C}_{6} \mathrm{H}_{9} \mathrm{O}_{10}$ & $100 \%$ & $242 / 305.00889$ \\
$<1 \%$ & $224 / 287.0024$ & & \\
$241 / 304.00582$ & 2 & & \\
\hline
\end{tabular}

a hydroxy-peroxy path Sequence 3

ing $\alpha$-pinene and $\Delta-3$-carene, and from ozonolysis of (Z)-6nonenal. In contrast, ozonolysis of 1-heptene, (Z)-6-nonenol and 5-hexen-2-on did not lead to substantial formation of highly oxidized molecules. In all the positive cases, the mass spectra were dominated by few peaks, analogous to Figs. 1 and 2, and these are listed in Tables 4-10, 12, and 13. All 
Table 6. HOM observed during ozonolysis of cycloheptene. The second header line shows at which molar masses the termination products are expected relative to the peroxy radical with molar mass $m$ (unit masses). Filled cells indicate that these compounds were detected with given elemental composition and relative intensity (second line in the same cell). Relative intensities were normalized to the largest HOM signal. The third line in the cell gives the molar mass [Da] in unit mass resolution and the precise $m / z$ [Th] at which the molecule was detected as cluster with ${ }^{15} \mathrm{NO}_{3}^{-}$.

\begin{tabular}{llll}
\hline Peroxy radical & Carbonyl & Hydroxy & Hydroperoxy \\
\hline$m$ & $m-17$ & $m-15$ & $m+1$ \\
\hline & $\mathrm{C}_{7} \mathrm{H}_{10} \mathrm{O}_{5}$ & & \\
& $<1 \%$ \\
& $174 / 237.0395$ & & \\
& & \\
$\mathrm{C}_{7} \mathrm{H}_{11} \mathrm{O}_{7}^{\mathrm{a}}$ & & \\
$<1 \%$ & & \\
$206 / 269.0462$ & & \\
\hline $\mathrm{C}_{7} \mathrm{H}_{11} \mathrm{O}_{8}$ & $\mathrm{C}_{7} \mathrm{H}_{10} \mathrm{O}_{7}$ & $\mathrm{C}_{7} \mathrm{H}_{12} \mathrm{O}_{7}$ & \\
$2 \%$ & $3 \%$ & $<1 \%$ & \\
$223 / 286.02945$ & $206 / 269.02775$ & $208 / 271.0409$ & \\
\hline \multicolumn{5}{c}{$\mathrm{C}_{7} \mathrm{H}_{10} \mathrm{O}_{8}^{\mathrm{a}}$} & & \\
& $8 \%$ & & \\
& $222 / 285.02306$ & & $256 / 319.02544$ \\
\hline $\mathrm{C}_{7} \mathrm{H}_{11} \mathrm{O}_{10}$ & $\mathrm{C}_{7} \mathrm{H}_{10} \mathrm{O}_{9}$ & & \\
$1 \%$ & $100 \%$ & & \\
$255 / 318.02027$ & $238 / 301.01758$ & & \\
\hline $\mathrm{C}_{7} \mathrm{H}_{11} \mathrm{O}_{11}^{\mathrm{a}}$ & $\mathrm{C}_{7} \mathrm{H}_{10} \mathrm{O}_{10}^{\mathrm{a}}$ & & \\
$<1 \%$ & $<1 \%$ & & \\
$271 / 334.01508$ & $254 / 317.0141$ & & \\
\hline & & & \\
\hline
\end{tabular}

a hydroxy-peroxy path Sequence 3

these compounds have in common that the respective starting peroxy radicals of type $\mathrm{S} 2$ or S4a,b in Fig. 3 can be formed.

The absence of highly oxidized molecules of 1-heptene, (Z)-6-nonenol, and especially 5-hexen-2-on suggests that an aldehyde group at the $\omega-\mathrm{C}$ atom facilitate $\mathrm{HOM}$ formation. No functionality $\left(\mathrm{CH}_{3}-\right)$, a methyl-oxo group $\mathrm{CH}_{3}--\mathrm{C}(=\mathrm{O})-$, or an alcohol group $\mathrm{HO}-\mathrm{CH}_{2}$ - at the $\omega$-end of the molecule obviously do not strongly promote formation of HOM. The positive results for 1-methyl-cyclohexene, and both monoterpenes (MT) indicate that the peroxy radical group can be located either in $\alpha$-position to a keto- or an aldehyde group. Applying our scheme, this means that $\omega-$ aldehyde functionality in peroxy radicals $\mathrm{S} 2$ and $\mathrm{S} 4 \mathrm{a}, \mathrm{b}$ in Fig. 3 favors $\mathrm{H}$ shifts, while the other groups in S5-S7 do not.
Table 7. HOM observed during ozonolysis of (Z)-6-nonenal. The second header line shows at which molar masses the termination products are expected relative to the peroxy radical with molar mass $m$ (unit masses). Filled cells indicate that these compounds were detected with given elemental composition and relative intensity (second line in the same cell). Relative intensities were normalized to the largest HOM signal. The third line in the cell gives the molar mass [Da] in unit mass resolution and the precise $m / z$ [Th] at which the molecule was detected as cluster with ${ }^{15} \mathrm{NO}_{3}^{-}$.

\begin{tabular}{llll}
\hline Peroxy radical & Carbonyl & Hydroxy & Hydroperoxy \\
\hline$m$ & $m-17$ & $m-15$ & $m+1$ \\
\hline $\mathrm{C}_{6} \mathrm{H}_{9} \mathrm{O}_{8}$ & & \\
$10 \%$ & & \\
$209 / 272.0151$ & & \\
\hline $\mathrm{C}_{6} \mathrm{H}_{9} \mathrm{O}_{9}^{\mathrm{a}}$ & & \\
$3 \%$ & & \\
$225 / 288.0101$ & & \\
\hline $\mathrm{C}_{6} \mathrm{H}_{8} \mathrm{O}_{10}$ & $\mathrm{C}_{6} \mathrm{H}_{8} \mathrm{O}_{9}$ & \\
$5 \%$ & $100 \%$ & \\
$241 / 304.0050$ & $224 / 287.0022$ & \\
\hline
\end{tabular}

a hydroxy-peroxy path Sequence 3

\section{Discussion}

\subsection{Unsubstituted cycloalkenes, peroxy radicals, and (Z)-6-nonenal}

Tables 4, 5, and 6 list the molecular masses of the organic moieties that were attributed to highly oxidized molecules, derived from the mass spectra for the cases of cyclopentene, cyclohexene, and cycloheptene. The mass of the nitrate ion was subtracted and termination products of peroxy radicals with mass $m$ were classified as by $m-17$ (carbonyl), $m-15$ (hydroxy) and $m+1$ (hydroperoxy), as in Table 2 of Sect. 3. Only such molecular structures that were indeed observed are noted, together with their molecular mass and the precise $\mathrm{m} / \mathrm{z}$ at which the molecules were detected as cluster with $\mathrm{NO}_{3}^{-}$. Clearly, we did not find all possible intermediates and termination products derived in Sect. 3 .

As shown already in Fig. 1, we often observed quite strong peaks at such odd masses $m$ where we would expect the peroxy radicals. From the molecular formula alone, which is assessable by APi-TOF-MS, their chemical character as alkyl, alkoxy or peroxy radicals cannot be distinguished. Alkoxy and alkyl radicals react with the $\mathrm{O}_{2}$ in air, while peroxy radicals react mainly with other peroxy radicals or NO, the latter being low in our experiments. We can exclude alkyl and alkoxy radicals, as their lifetime is too short to allow for formation in measurable amounts (and to survive in the APiTOF-MS). Other candidates would be organic nitrates, which we exclude by the observed mass defects and because of our low $\mathrm{NO}_{x}$ conditions. Moreover, highly oxidized nitrates 
Table 8. HOM observed during ozonolysis of 1methylcyclohexene. The second header line shows at which molar masses the termination products are expected relative to the peroxy radical with molar mass $m$ (unit masses). Filled cells indicate that these compounds were detected with given elemental composition and relative intensity (second line in the same cell). Relative intensities were normalized to the largest HOM signal. The third line in the cell gives the molar mass [Da] in unit mass resolution and the precise $\mathrm{m} / \mathrm{z}$ [Th] at which the molecule was detected as cluster with ${ }^{15} \mathrm{NO}_{3}^{-}$.

\begin{tabular}{llll}
\hline Peroxy radical & Carbonyl & Hydroxy & Hydroperoxy \\
\hline$m$ & $m-17$ & $m-15$ & $m+1$ \\
\hline $\mathrm{C}_{7} \mathrm{H}_{11} \mathrm{O}_{6}$ & $\mathrm{C}_{7} \mathrm{H}_{10} \mathrm{O}_{5}$ & & \\
$<1 \%$ & $<1 \%$ & & \\
$191 / 254.03857$ & $174 / 237.03855$ & & \\
\hline $\mathrm{C}_{7} \mathrm{H}_{11} \mathrm{O}_{7}^{\mathrm{a}}$ & $\mathrm{C}_{7} \mathrm{H}_{10} \mathrm{O}_{6}^{\mathrm{a}}$ & & \\
$<1 \%$ & $1 \%$ & & \\
$207 / 270.03179$ & $190 / 253.0331$ & & $\mathrm{C}_{7} \mathrm{H}_{12} \mathrm{O}_{8}$ \\
\hline $\mathrm{C}_{7} \mathrm{H}_{11} \mathrm{O}_{8}$ & $\mathrm{C}_{7} \mathrm{H}_{10} \mathrm{O}_{7}$ & $\mathrm{C}_{7} \mathrm{H}_{12} \mathrm{O}_{7}$ & $1 \%$ \\
$2 \%$ & $100 \%$ & $2 \%$ & $224 / 287.04046$ \\
$223 / 286.03086$ & $206 / 269.02829$ & $208 / 271.3858$ & \\
\hline $\mathrm{C}_{7} \mathrm{H}_{11} \mathrm{O}_{9}^{\mathrm{a}}$ & & & \\
$<1 \%$ & & & \\
$239 / 302.02700$ & & & \\
\hline & $\mathrm{C}_{7} \mathrm{H}_{10} \mathrm{O}_{9}$ & $\mathrm{C}_{7} \mathrm{H}_{12} \mathrm{O}_{9}$ & \\
& $<1 \%$ & $<1 \%$ & \\
& $238 / 301.01326$ & $240 / 303.03521$ & \\
\hline
\end{tabular}

a hydroxy-peroxy path Sequence 3

would be expected at $m+30$, so they cannot interfere with $\mathrm{O}$ or $\mathrm{O}_{2}$ progressions of $m$. A contribution of ${ }^{13} \mathrm{C}$ isotope can be excluded if there is no strong signal at $m-1$. We conclude that the strong peaks at $m$ are peroxy radicals. It is known that peroxy radicals can have lifetimes of minutes (e.g., Finlayson-Pitts and Pitts Jr., 2000, Sect. 6.D.2.e), so they can be built up in high enough concentrations and obviously survive in our APi-TOF-MS. HOM peroxy radicals were also observed in previous studies (Ehn et al., 2014; Jokinen et al., 2014; Rissanen et al., 2014). However, in the case of a significant contribution of the hydroxy-peroxy path leading to hydroxy-peroxy radicals at $m+16$ the corresponding carbonyl termination product resides at the $m-1$ $(m+16-17)$ position. In these cases, the ${ }^{13} \mathrm{C}$ contribution of the carbonyl termination product at $m$ must be considered and corrected.

According to the scheme in Table 2, the starting point for formation of highly oxidized molecules is the peroxy radical of type S2 (Sequence 1) with $R=\left(\mathrm{CH}_{2}\right)_{2-4}$ and four $\mathrm{O}$ atoms. The first-detected peroxy radicals were $\mathrm{C}_{5} \mathrm{H}_{7} \mathrm{O}_{8}$, $\mathrm{C}_{6} \mathrm{H}_{9} \mathrm{O}_{8}$, and $\mathrm{C}_{7} \mathrm{H}_{11} \mathrm{O}_{8}$ and the most oxidized were the $\mathrm{O}_{10^{-}}$ analogues (Tables 4-6). Peroxy radicals with odd oxygen numbers likely involve alkoxy rearrangement Sequence 3 at one step. We will discuss both findings later in detail.
Table 9. HOM products observed during ozonolysis of 3methylcyclohexene. The second header line shows at which molar masses the termination products are expected relative to the peroxy radical with molar mass $m$ (unit masses). Filled cells indicate that these compounds were detected with given elemental composition and relative intensity (second line in the same cell). Relative intensities were normalized to the largest HOM signal. The third line in the cell gives the molar mass [Da] in unit mass resolution and the precise $m / z$ [Th] at which the molecule was detected as cluster with ${ }^{15} \mathrm{NO}_{3}^{-}$.

\begin{tabular}{llll}
\hline Peroxy radical & Carbonyl & Hydroxy & Hydroperoxy \\
\hline$m$ & $m-17$ & $m-15$ & $m+1$ \\
\hline & $\mathrm{C}_{7} \mathrm{H}_{10} \mathrm{O}_{5}$ & \\
& $<1 \%$ \\
& $174 / 237.0382$ & \\
& $\mathrm{C}_{7} \mathrm{H}_{10} \mathrm{O}_{6}^{\mathrm{a}}$ & \\
& $<1 \%$ \\
& $190 / 253.0331$ & \\
& $\mathrm{C}_{7} \mathrm{H}_{12} \mathrm{O}_{8}$ \\
$\mathrm{C}_{7} \mathrm{H}_{11} \mathrm{O}_{8}$ & $\mathrm{C}_{7} \mathrm{H}_{10} \mathrm{O}_{7}$ & $6 \%$ \\
$12 \%$ & $25 \%$ & $224 / 287.0386$ \\
$223 / 286.0308$ & $206 / 269.0281$ & \\
\hline $\mathrm{C}_{7} \mathrm{H}_{11} \mathrm{O}_{9}^{\mathrm{a}}$ & $\mathrm{C}_{7} \mathrm{H}_{10} \mathrm{O}_{8}^{\mathrm{a}}$ & & \\
$5 \%$ & $19 \%$ & & \\
$239 / 302.0257$ & $222 / 285.0230$ & & \\
\hline $\mathrm{C}_{7} \mathrm{H}_{11} \mathrm{O}_{10}$ & $\mathrm{C}_{7} \mathrm{H}_{10} \mathrm{O}_{9}$ & $\mathrm{C}_{7} \mathrm{H}_{12} \mathrm{O}_{9}$ \\
$9 \%$ & $100 \%$ & $13 \%$ & \\
$255 / 318.0206$ & $238 / 301.0179$ & $240 / 303.0335$ \\
\hline
\end{tabular}

a hydroxy-peroxy path Sequence 3

The next columns in Tables 4-6 list the stable HOM produced in termination reactions from the peroxy radical in the first column. All intensities were normalized to the strongest signal. For cyclohexene and cycloheptene this is the $\mathrm{O}_{9}$ carbonyl termination product $(m-17)$ which is formed from the peroxy radical carrying $10 \mathrm{O}$ atoms either via Reactions (R5), (R6) (Sequence 2) or, as shown by Rissanen et al. (2014), via Reaction (R9c) (Sequence 4). The corresponding peak is second largest for cyclopentene; here the $\mathrm{O}_{7-}$ carbonyl termination product from the precursor peroxy radical with eight $\mathrm{O}$ atoms is about a factor of 2 larger (Table 4). The analogous product appeared also for cyclohexene, however contributing only $20 \%$ of the largest carbonyl termination product (Table 5), and it is unimportant for cycloheptene (Table 6). In general, carbonyl termination products $(m-17)$ arising from Reactions (R5) and (R6) are expected to be the major products at typical atmospheric concentrations of $\mathrm{NO}$, $\mathrm{HO}_{2}$, and $\mathrm{RO}_{2}$.

Compared to carbonyl termination products, hydroxy $(m-$ $15)$ and hydroperoxy termination products $(m+1)$ are less important termination products and only for cyclopentene we find significant contribution of hydroxy and hydroperoxy termination products of $10-20 \%$. Their contribution is 
Table 10. HOM products observed during ozonolysis of 4-methylcyclohexene. The second header line shows at which molar masses the termination products are expected relative to the peroxy radical with molar mass $m$ (unit masses). Filled cells indicate that these compounds were detected with given elemental composition and relative intensity (second line in the same cell). Relative intensities were normalized to the largest HOM signal. The third line in the cell gives the molar mass [Da] in unit mass resolution and the precise $m / z$ [Th] at which the molecule was detected as cluster with ${ }^{15} \mathrm{NO}_{3}^{-}$.

\begin{tabular}{|c|c|c|c|}
\hline Peroxy radical & Carbonyl & Hydroxy & Hydroperoxy \\
\hline \multirow[t]{2}{*}{$m$} & $m-17$ & $m-15$ & $m+1$ \\
\hline & $\begin{array}{l}\mathrm{C}_{7} \mathrm{H}_{10} \mathrm{O}_{5} \\
<1 \% \\
174 / 237.03635\end{array}$ & & \\
\hline $\begin{array}{l}\mathrm{C}_{7} \mathrm{H}_{11} \mathrm{O}_{7}^{\mathrm{a}} \\
<1 \% \\
207 / 270.0359\end{array}$ & $\begin{array}{l}\mathrm{C}_{7} \mathrm{H}_{10} \mathrm{O}_{6}^{\mathrm{a}} \\
<1 \% \\
190 / 253.03390\end{array}$ & & \\
\hline $\begin{array}{l}\mathrm{C}_{7} \mathrm{H}_{11} \mathrm{O}_{8} \\
<1 \% \\
223 / 286.02825\end{array}$ & $\begin{array}{l}\mathrm{C}_{7} \mathrm{H}_{10} \mathrm{O}_{7} \\
2 \% \\
206 / 269.0281\end{array}$ & $\begin{array}{l}\mathrm{C}_{7} \mathrm{H}_{12} \mathrm{O}_{7} \\
<1 \% \\
208 / 271.0437\end{array}$ & $\begin{array}{l}\mathrm{C}_{7} \mathrm{H}_{12} \mathrm{O}_{8} \\
<1 \% \\
224 / 287.03770\end{array}$ \\
\hline $\begin{array}{l}\mathrm{C}_{7} \mathrm{H}_{11} \mathrm{O}_{9}^{\mathrm{a}} \\
<1 \% \\
239 / 302.0224\end{array}$ & $\begin{array}{l}\mathrm{C}_{7} \mathrm{H}_{10} \mathrm{O}_{8}^{\mathrm{a}} \\
5 \% \\
222 / 285.02215\end{array}$ & & \\
\hline $\begin{array}{l}\mathrm{C}_{7} \mathrm{H}_{11} \mathrm{O}_{10} \\
2 \% \\
255 / 318.02114\end{array}$ & $\begin{array}{l}\mathrm{C}_{7} \mathrm{H}_{10} \mathrm{O}_{9} \\
100 \% \\
238 / 301.01848\end{array}$ & & $\begin{array}{l}\mathrm{C}_{7} \mathrm{H}_{12} \mathrm{O}_{10} \\
<1 \% \\
256 / 319.02566\end{array}$ \\
\hline $\begin{array}{l}\mathrm{C}_{7} \mathrm{H}_{11} \mathrm{O}_{11}^{\mathrm{a}} \\
<1 \% \\
271 / 334.01626\end{array}$ & $\begin{array}{l}\mathrm{C}_{7} \mathrm{H}_{10} \mathrm{O}_{10}^{\mathrm{a}} \\
1 \% \\
254 / 317.01331\end{array}$ & & \\
\hline $271 / 334.01626$ & $\begin{array}{l}\mathrm{C}_{7} \mathrm{H}_{10} \mathrm{O}_{11} \\
<1 \% \\
270 / 333.01163\end{array}$ & $\begin{array}{l}\mathrm{C}_{7} \mathrm{H}_{12} \mathrm{O}_{11} \\
<1 \% \\
272 / 335.02524\end{array}$ & \\
\hline
\end{tabular}

${ }^{a}$ hydroxy-peroxy path Sequence 3

decreasing with increasing chain length, and their contribution in the case of cycloheptene is less than $1 \%$. Increasing chain length may make the geometry of the $\mathrm{H}$ shift more favorable (i.e., 1,6 instead of 1,5 or 1,4 etc.). Thus, the $\mathrm{H}$ shifts of longer-chain peroxy radicals become faster, while bimolecular reactions are more or less unchanged, thus giving more carbonyl termination products in relation to hydroxy and hydroperoxy termination products. The detailed product distribution must be also dependent on the reaction conditions, i.e., reactant and oxidant concentrations, temperature etc. For example the formation of hydroperoxy groups is controlled by $\mathrm{HO}_{2} / \mathrm{RO}_{2}$ ratio and we did not take specific measures to hold this ratio constant.

For cyclopentene the hydroperoxide $\mathrm{C}_{5} \mathrm{H}_{8} \mathrm{O}_{8}$ provides a substantial contribution of $19 \%$ under the given conditions. $\mathrm{C}_{5} \mathrm{H}_{8} \mathrm{O}_{8}$ can be either the hydroperoxy termination product from $\mathrm{C}_{5} \mathrm{H}_{7} \mathrm{O}_{8}+\mathrm{HO}_{2}$ (Reaction $\mathrm{R} 4$ ) or an hydroxy termina-
Table 11. Comparison of HOM products resulting from $\mathrm{C}_{7} \mathrm{H}_{14}$ compounds.

\begin{tabular}{lcccc}
\hline & Cycloheptene & $1-\mathrm{MCH}$ & $3-\mathrm{MCH}$ & $4-\mathrm{MCH}$ \\
\hline Peroxy radical & & & & \\
\hline $\mathrm{C}_{7} \mathrm{H}_{11} \mathrm{O}_{6}$ & - & $\times$ & - & - \\
$\mathrm{C}_{7} \mathrm{H}_{11} \mathrm{O}_{8}$ & $\times$ & $\times$ & $\times$ & $\times$ \\
$\mathrm{C}_{7} \mathrm{H}_{11} \mathrm{O}_{10}$ & $\times$ & - & $\times$ & $\times$ \\
\hline $\mathrm{Carbonyl}_{7}$ & & & & \\
\hline $\mathrm{C}_{7} \mathrm{H}_{10} \mathrm{O}_{5}$ & $\times$ & $\times$ & $\times$ & $\times$ \\
$\mathrm{C}_{7} \mathrm{H}_{10} \mathrm{O}_{7}$ & $\times$ & $\times$ & $\times$ & $\times$ \\
$\mathrm{C}_{7} \mathrm{H}_{10} \mathrm{O}_{9}$ & $\times$ & $\times$ & $\times$ & $\times$ \\
$\mathrm{C}_{7} \mathrm{H}_{10} \mathrm{O}_{11}$ & - & - & - & $\times$ \\
\hline $\mathrm{Hydroxy}_{7}$ & & & & \\
\hline $\mathrm{C}_{7} \mathrm{H}_{12} \mathrm{O}_{7}$ & $\times$ & $\times$ & - & $\times$ \\
$\mathrm{C}_{7} \mathrm{H}_{12} \mathrm{O}_{9}$ & - & $\times$ & $\times$ & - \\
$\mathrm{C}_{7} \mathrm{H}_{12} \mathrm{O}_{11}$ & - & - & - & $\times$ \\
\hline $\mathrm{Hydroperoxy}_{7 y}$ & & & & \\
\hline $\mathrm{C}_{7} \mathrm{H}_{12} \mathrm{O}_{6}$ & - & interference & - & - \\
$\mathrm{C}_{7} \mathrm{H}_{12} \mathrm{O}_{8}$ & - & $\times$ & $\times$ & $\times$ \\
$\mathrm{C}_{7} \mathrm{H}_{12} \mathrm{O}_{10}$ & $\times$ & - & - & $\times$ \\
\hline $\mathrm{Hydroxy}_{7}$ peroxy radical & & $\times$ & $\times$ \\
\hline $\mathrm{C}_{7} \mathrm{H}_{11} \mathrm{O}_{7}$ & $\times$ & $\times$ & - & $\times$ \\
$\mathrm{C}_{7} \mathrm{H}_{11} \mathrm{O}_{9}$ & - & $\times$ & $\times$ & $\times$ \\
$\mathrm{C}_{7} \mathrm{H}_{11} \mathrm{O}_{11}$ & $\times$ & - & - & $\times$ \\
\hline $\mathrm{Hydroxy}_{2}$ peroxy path carbonyl & & & \\
\hline $\mathrm{C}_{7} \mathrm{H}_{10} \mathrm{O}_{6}$ & - & $\times$ & & \\
$\mathrm{C}_{7} \mathrm{H}_{10} \mathrm{O}_{8}$ & $\times$ & - & & \\
$\mathrm{C}_{7} \mathrm{H}_{10} \mathrm{O}_{10}$ & $\times$ & & & \\
\hline & & & & \\
\hline
\end{tabular}

tion product formed in reaction (R5, Sequence 2) including the hydroxy-peroxy radical $\mathrm{C}_{5} \mathrm{H}_{7} \mathrm{O}_{9}$. Both lead to same isobaric mass (Table 4). Since the corresponding carbonyl termination product is missing and the precursor $\mathrm{C}_{5} \mathrm{H}_{7} \mathrm{O}_{9}$ of the hydroxy termination product is much less abundant than that of the hydroperoxy product $\mathrm{C}_{5} \mathrm{H}_{7} \mathrm{O}_{8}$, we suggest that the main fraction of the peak observed for $\mathrm{C}_{5} \mathrm{H}_{8} \mathrm{O}_{8}$ is the hydroperoxy termination product.

As is obvious from Tables 4 and 5, for cyclopentene and cyclohexene, only molecules with more than seven oxygen atoms were detected. However, as can be seen in Table 6 for cycloheptene, five or fewer $\mathrm{O}$ atoms can be detected for $\mathrm{C}_{7}$ compounds, but only in traces. This is corroborated by Tables 7 for (Z)-6-nonenal and Tables 8 and 9 for the methylcyclohexenes.

We can already deduce some rules for formation of HOM from the results of cyclopentene, cyclohexene and cycloheptene and construct a mechanistic scheme as shown in Fig. 4 (cf. Rissanen et al., 2014). The most abundant peaks in the monomer range of $\mathrm{HOM}$ can be attributed to products 


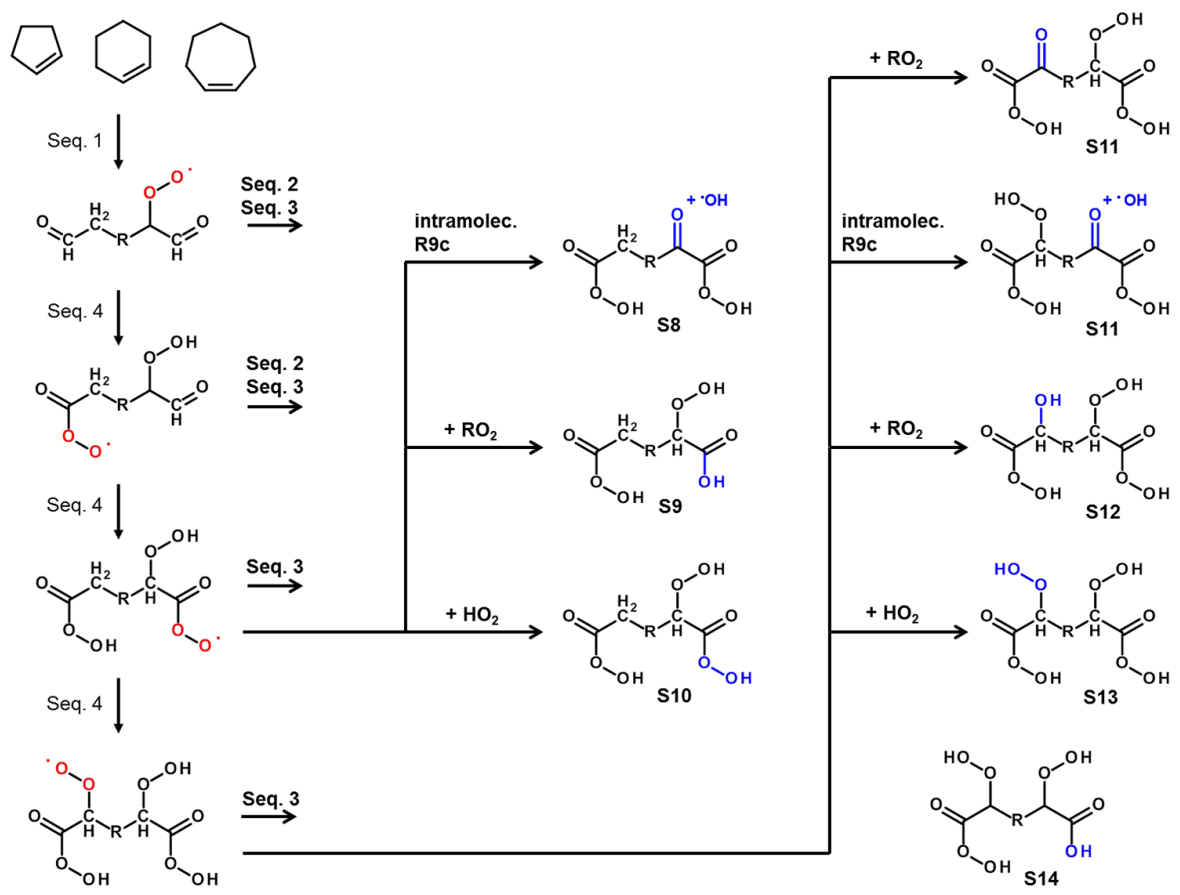

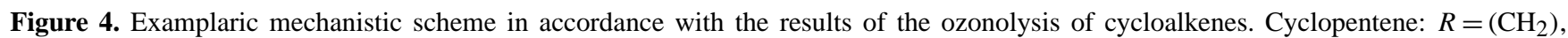
cyclohexene: $R=\left(\mathrm{CH}_{2}\right)_{2}$, cycloheptene: $R=\left(\mathrm{CH}_{2}\right)_{3}$. The peroxy radicals with increasing number of $\mathrm{O}$ atoms $(\mathrm{m} / z=m)$ on the left-hand side are formed by autoxidation (Sequence 4). They can undergo either termination reactions in Sequence 2 or follow the hydroxy-peroxy path (Sequence 3$)$. The carbonyl $(m-17)$, hydroxy $(m-15)$ and hydroperoxy $(m+1)$ termination products are shown for the $\mathrm{O}_{8}-$ peroxy radical (S8-S10) and the $\mathrm{O}_{10}$-peroxy radical (S11-S12) in the middle and right hand column, respectively. The functional groups formed by the termination reactions are shown in blue. The products S8 and S11 from the intramolecular termination (Reaction R9c) are the same as for the intermolecular termination Reactions (R5a) and (R6b). Note that in principle, the series of rearrangements can be also permuted. If the $\mathrm{H}$ atoms at the $\mathrm{C}$ atom in $\alpha$-position to the second aldehyde group are subject to $\mathrm{H}$ shift before attack on the aldehyde group itself, structures like $\mathrm{S} 14$ could be formed, isobaric to $\mathrm{S} 12$.

preserving the $\mathrm{C}$ atom number of the precursor. They form regular patters in the mass spectra, which can be explained by expected termination products of $\mathrm{RO}_{2}$ termination reactions Sequence 2 and the intramolecular termination (R9c) (Rissanen et al., 2014), either directly via the peroxy path Sequence 4 or via an alternative, the hydroxy-peroxy path, involving alkoxy rearrangement Sequence 3 as intermediate step.

Stable, closed-shell termination products are most abundant. Carbonyl termination products (S8, S11) are more abundant than hydroperoxy (S10, S13) and hydroxy termination products (S9, S12, S14) and all together they are more abundant than the peroxy radicals. Products of the hydroxyperoxy path gain importance with increasing chain length, but remain sparse and less abundant than products from the peroxy path. Independent of the chain length, the maximum number of $\mathrm{O}$ atoms observed in peroxy radicals and hydroperoxides is ten, or nine for corresponding carbonyl and hydroxy termination products, because here one $\mathrm{O}$ atom is lost in termination Reactions (R5) and (R6a) (Sequence 2). The starting radicals $\mathrm{S} 2$ have four $\mathrm{O}$ atoms - two carbonyl end groups $(2 \times \mathrm{O})$ and a peroxy functionality $\left(1 \times \mathrm{OO}^{\circ}\right)$ in $\alpha$-position to one of the end groups. Therefore, the $\mathrm{H}$ shift $/ \mathrm{O}_{2}$-addition mechanism of peroxy radicals can operate up to three times introducing up to six further $\mathrm{O}$ atoms. This together with the sensitivity of formation of highly oxidized molecules to an aldehyde $\omega$-terminal group (Table 3 ) suggest that $\mathrm{H}$ shifts, which are competitive at the experimental peroxy radical lifetimes, are limited to the two terminal $\mathrm{C}$ atoms and the two $\mathrm{C}$ atoms in $\alpha$-position to them. The $\mathrm{H}$ atoms of the aldehyde groups are relative weakly bound (Rissanen et al., 2014) and so it is not surprising that they are preferably attacked as shown in the first steps on the left-hand side in Fig. 4. (Additional constraints are the steric availability of the $\mathrm{H}$ atoms.) In general the binding energy of an $\mathrm{H}$ atom to a $\mathrm{C}$ atom depends on the functional group added to the respective $\mathrm{C}$ atom. Low binding energies certainly will favor $\mathrm{H}$ shifts (given a suited geometry) and therefore favor the autoxidation mechanism (e.g., Glowacki and Pilling, 2010).

Attack on aldehyde $\mathrm{H}$ atom leads to peroxy radicals of type $-\mathrm{C}(=\mathrm{O}) \mathrm{OO}^{*}$ and after further $\mathrm{H}$ shift to percarboxylic acid groups $-\mathrm{C}(=\mathrm{O}) \mathrm{OOH}$ (Fig. 4). We suggest that percarboxylic acid groups are able to activate the $\mathrm{H}$ atoms at their neighbor $\mathrm{C}$ atom in $\alpha$-position. This will support one more 
Table 12. HOM products observed during ozonolysis of $\alpha$-pinene. The second header line shows at which molar masses the termination products are expected relative to the peroxy radical with molar mass $m$ (unit masses). Filled cells indicate that these compounds were detected with given elemental composition and relative intensity (second line in the same cell). Relative intensities were normalized to the largest HOM signal. The third line in the cell gives the molar mass [Da] in unit mass resolution and the precise $m / z$ [Th] at which the molecule was detected as cluster with ${ }^{15} \mathrm{NO}_{3}^{-}$.

\begin{tabular}{llll}
\hline Peroxy radical & Carbonyl & Hydroxy & Hydroperoxy \\
\hline$m$ & $m-17$ & $m-15$ & $m+1$ \\
\hline $\mathrm{C}_{10} \mathrm{H}_{15} \mathrm{O}_{8}$ & $\mathrm{C}_{10} \mathrm{H}_{14} \mathrm{O}_{7}$ & & \\
$46 \%$ & $88 \%$ & & \\
$263 / 326.0621$ & $264 / 309.0594$ & & \\
\hline $\mathrm{C}_{10} \mathrm{H}_{15} \mathrm{O}_{9}^{\mathrm{a}}$ & $\mathrm{C}_{10} \mathrm{H}_{14} \mathrm{O}_{8}^{\mathrm{a}}$ & & \\
$5 \%$ & $14 \%$ & & \\
$279 / 342.0570$ & $262 / 325.0543$ & & $\mathrm{C}_{10} \mathrm{H}_{16} \mathrm{O}_{10}$ \\
$\mathrm{C}_{10} \mathrm{H}_{15} \mathrm{O}_{10}$ & $\mathrm{C}_{10} \mathrm{H}_{14} \mathrm{O}_{9}$ & $\mathrm{C}_{10} \mathrm{H}_{16} \mathrm{O}_{9}$ & $37 \%$ \\
$40 \%$ & $83 \%$ & $100 \%$ & $296 / 359.0597$ \\
$295 / 358.0519$ & $326 / 341.0492$ & $280 / 343.0648$ & \\
\hline & $\mathrm{C}_{10} \mathrm{H}_{14} \mathrm{O}_{11}^{\mathrm{a}}$ & $\mathrm{C}_{10} \mathrm{H}_{16} \mathrm{O}_{11}^{\mathrm{a}}$ & \\
& $69 \%$ & $29 \%$ & \\
& $327 / 373.0390$ & $312 / 375.0547$ & \\
\hline
\end{tabular}

a hydroxy-peroxy path Sequence 3

autoxidation step. Termination here can lead to the dominant carbonyl termination products. From these observations we deduce that a highly oxidized carbonyl compound should have the structure S11 in Fig. 4, i.e., a di-percarboxylic acid with hydroperoxide group and keto group, both in $\alpha$-position to the percarboxylic acid groups, at least in the case of the plain cycloalkenes discussed here. Assuming that a percarboxylic acid group is required for $\mathrm{H}$-shift activation at its neighboring $\alpha-\mathrm{C}$ atom, the corresponding hydroperoxy and hydroxy termination products should look like structures S12 and S10 in Fig. 4.

If the percarboxylic group is able to activate the $\mathrm{H}$ atoms at its $\alpha$-C atom in order to be competitive with a shift of an aldehyde- $\mathrm{H}$, the final attack could also occur at the aldehyde group. This would lead to either S13 under hydroperoxy termination or to the structure S14, a mixed carboxyl percarboxylic di-acid with hydroperoxide groups at the $\mathrm{C}$ atoms in $\alpha$ position of the acid functions, isobaric to S12 in Fig. 4.

Our interpretations are corroborated by the findings for (Z)-6-nonenal. Ozonolysis of (Z)-6-nonenal leads to either a $\mathrm{C}_{3}$-Criegee intermediate and a $\mathrm{C}_{6}$-dialdehyde, or propanal and a $\mathrm{C}_{6}$-Criegee intermediate. Via the vinylhydroperoxide path the latter forms the same starting peroxy radical as the ring opening of cyclohexene. Indeed, two peroxy radicals were detected for (Z)-6-nonenal and the dominant peak is the carbonyl termination product from the $\mathrm{O}_{10}$-peroxy radical (Table 7).
Table 13. HOM products observed during ozonolysis of $\Delta-3$ carene. The second header line shows at which molar masses the termination products are expected relative to the peroxy radical with molar mass $m$ (unit masses). Filled cells indicate that these compounds were detected with given elemental composition and relative intensity (second line in the same cell). Relative intensities were normalized to the largest HOM signal. The third line in the cell gives the molar mass [Da] in unit mass resolution and the precise $m / z$ [Th] at which the molecule was detected as cluster with ${ }^{15} \mathrm{NO}_{3}^{-}$.

\begin{tabular}{llll}
\hline Peroxy radical & Carbonyl & Hydroxy & Hydroperoxy \\
\hline$m$ & $m-17$ & $m-15$ & $m+1$ \\
\hline $\mathrm{C}_{10} \mathrm{H}_{15} \mathrm{O}_{8}$ & & & \\
$10 \%$ & & & \\
$263 / 326.0621$ & & & \\
\hline $\mathrm{C}_{10} \mathrm{H}_{15} \mathrm{O}_{10}$ & $\mathrm{C}_{10} \mathrm{H}_{14} \mathrm{O}_{9}$ & $\mathrm{C}_{10} \mathrm{H}_{16} \mathrm{O}_{9}$ & \\
$94 \%$ & $295 / 358.0519$ & $100 \%$ & \\
$47 \%$ & $278 / 341.0492$ & $280 / 343.0648$ & \\
\hline
\end{tabular}

\subsection{Methyl substitution of cyclohexene}

In order to support the suggested reaction path to HOM in Fig. 4, we now will investigate the effect of methyl substitution of the double bond. This is also one step further towards $\alpha$-pinene, the most abundant MT, which forms ELVOC in the atmosphere (Ehn et al., 2012, 2014). Table 8 lists the results for 1-methyl-cyclohexene. Here the largest peak is the carbonyl termination product $\mathrm{C}_{7} \mathrm{H}_{10} \mathrm{O}_{7}$ arising from the peroxy radical $\mathrm{C}_{7} \mathrm{H}_{11} \mathrm{O}_{8}$. The corresponding $\mathrm{O}_{7}$-hydroxy and $\mathrm{O}_{7}$-hydroperoxy termination products can be also identified. As in the case of cycloheptene, highly oxidized molecules with less than seven $\mathrm{O}$ atoms are detectable, but in very small amounts only. Compared to cycloheptene (and cyclohexene) the $\mathrm{HOM}$ arising from the $\mathrm{O}_{8}$ peroxy radical dominate, while termination products from the $\mathrm{O}_{10}$ peroxy radical are sparse.

The methyl substitution at the double bond introduces asymmetry, leading to three different vinylhydroperoxides and three different starting peroxy radicals S15-S17 (Fig. 5). The peroxy radical S17 in Fig. 5 has a methyl-oxo and not an aldehyde group as $\omega$-terminal group. In the case of 5hexen-2-on only the S17 analog, S5, (Fig. 3) is formed, and 5-hexen-2-on did not undergo HOM formation. Peroxy radicals in S15 and S16 (Fig. 5) can rearrange under $\mathrm{H}$ shift from the $\omega$-aldehyde group and subsequent $\mathrm{O}_{2}$ addition. $\mathrm{S} 15$ and S16 are similar with only the hydroperoxide group at different positions. According to the scheme developed here this should lead to the same set of isobaric products, and for clarity we will only follow the fate of peroxy radical S15. In the case of S15, the autoxidation mechanism would lead to peroxy radical S18 and in a further step to peroxy radical S19. S19 terminates in the usual way or intramolecular (Reaction R9c) to either ketones (S20, S21) or a hydroxy 


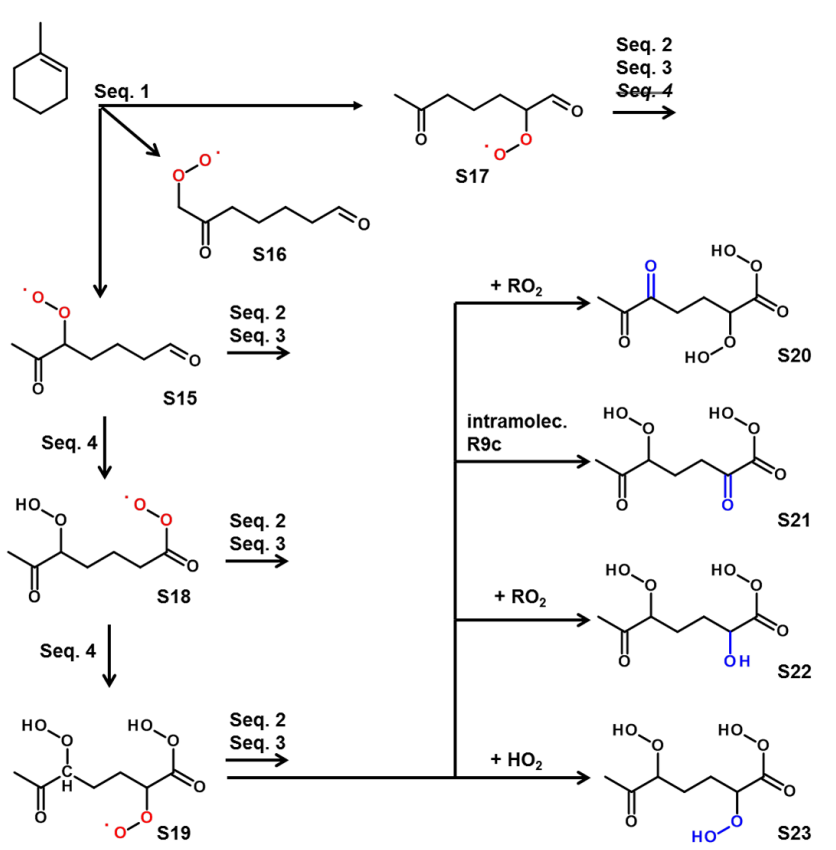

Figure 5. Schematics of HOM formation of 1-methyl cyclohexene. The major products are carbonyl termination products, either S20 or S21. Higher oxidation products are minor. Peroxy radical S17 has no terminal $\omega$-aldehyde group. Peroxy radical S16 will produce isobaric products analogous to $\mathrm{S} 15$.

product (S22), or a hydroperoxide (S23). The isobaric carbonyl termination products (S20, S21) are by far the largest contribution in the spectrum, as hydroxy and hydroperoxy termination products contribute only about $1-2 \%$ in total. It is notable that the maximum oxidation is indeed limited to seven or eight $\mathrm{O}$ atoms, two less compared to the major termination products of cycloheptene.

The products of 3- and 4-methyl-cyclohexene (Tables 10, 11 ), as well as cycloheptene (Table 6) show similar patterns. Methyl substitution leads only to minor variations of the cycloheptene HOM pattern with the 3-methyl-hexene being little more deviant. This could indicate steric effects, which fade if the methyl group moves away from the double bond, i.e., away from the molecule ends of the ring opening products susceptible to $\mathrm{H}$ shifts.

Table 9 compares the HOM of all $\mathrm{C}_{7}$ cycloalkenes investigated. As discussed, 1-methyl substitution leads to unique HOM pattern wherein the highest oxidation step is only very weakly expressed. This is likely caused by the fact that the ring opening for 1-methyl cyclohexene leads only to one aldehyde group, instead of two as for cycloheptene, 3-methyl-cyclohexene, and 4-methyl-cyclohexene.

In the case of 4-methyl cyclohexene (Table 11) we find small contributions of $\mathrm{C}_{7} \mathrm{H}_{10} \mathrm{O}_{11}$ indicating that in complex molecules, higher degrees of oxidation may be achieved. We hypothesize that the tertiary $\mathrm{H}$ atom at the methyl branching may be susceptible to $\mathrm{H}$ shift of peroxy groups. The observa-

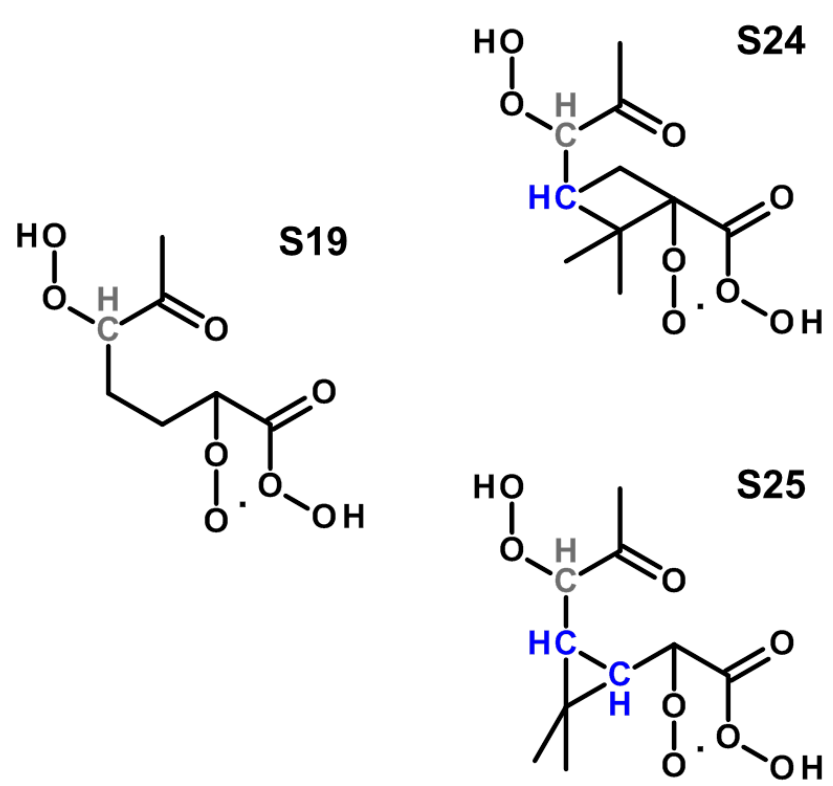

Figure 6. Comparison of deduced highest oxidized $\mathrm{O}_{8}$-peroxy radical of 1-methyl cyclohexene (S19) to analogously constructed $\mathrm{O}_{8}-$ peroxy radicals of $\alpha$-pinene (S24) and $\Delta$-3-carene (S25). Tertiary $\mathrm{H}$ atoms in blue are explicitly shown. The $\mathrm{H}$ at the carbon atom carrying the hydroperoxy group, which is shifted in Reaction (R9c) is shown in gray. In an isomeric modification, the hydroperoxide group at $\mathrm{C}_{3}$ could be located also at $\mathrm{C}_{1}$.

tion of the $\mathrm{O}_{11}$-carbonyl termination products suggests that the attack on the tertiary $\mathrm{H}$ atom is not necessarily the final step, as tertiary peroxy radicals cannot stabilize into ketones. If several $\mathrm{H}$ atoms are susceptible to $\mathrm{H}$ shift of peroxy groups - with different rates - permutation of pathways will occur according to the respective rate coefficients. For 3-methylcyclohexene, the effect of the tertiary peroxy radicals is not so distinct, because the methyl group resides on the $\alpha$-C atom next to an aldehyde group from which we expect $\mathrm{H}$ shift anyhow.

\subsection{Monoterpenes and tertiary $\mathrm{H}$ atoms}

Tables 12 and 13 show the result for two bicyclic MT, $\alpha$ pinene (cf. Ehn et al., 2014) and $\Delta$-3-carene. Both MT contain the same methyl-substituted six-ring structure as 1methyl cyclohexene. In the case of 1-methyl cyclohexene, we are quite confident that the highest peroxy radical should look like S19 in Figs. 5 and 6. If we construct the analogous peroxy radicals for $\alpha$-pinene and $\Delta$-3-carene, they should look like S24 and S25 in Fig. 6, so the maximum oxidation degree in analogy to the cycloalkenes should be limited as for 1-methyl-cyclohexene, i.e., either bimolecular or intramolecular termination.

Comparison shows that for the MT higher oxidation degrees were achieved (Tables 12 and 13). While for 1-methyl cyclohexene, the major termination product is a ketone with 
Table 14. Detected and identified dimers observed during ozonolysis of cyclopentene.

\begin{tabular}{ccc}
\hline$m / z[\mathrm{Th}]$ & Formula & Intensity [\%] \\
\hline 389.0339 & $\mathrm{C}_{10} \mathrm{H}_{14} \mathrm{O}_{12} \cdot{ }^{15} \mathrm{NO}_{3}^{-}$ & 44 \\
421.0238 & $\mathrm{C}_{10} \mathrm{H}_{14} \mathrm{O}_{14} \cdot{ }^{15} \mathrm{NO}_{3}^{-}$ & 100 \\
453.0136 & $\mathrm{C}_{10} \mathrm{H}_{14} \mathrm{O}_{16} \cdot{ }^{15} \mathrm{NO}_{3}^{-}$ & 2 \\
343.0648 & $\mathrm{C}_{10} \mathrm{H}_{16} \mathrm{O}_{9} \cdot{ }^{15} \mathrm{NO}_{3}^{-}$ & 24 \\
375.0547 & $\mathrm{C}_{10} \mathrm{H}_{16} \mathrm{O}_{11} \cdot{ }^{15} \mathrm{NO}_{3}^{-}$ & 6 \\
\hline
\end{tabular}

seven $\mathrm{O}$ atoms, $\alpha$-pinene and $\Delta$-3-carene generate substantial amounts of ketones with nine ( $\alpha$-pinene, $\Delta$-3-carene) or even 11 ( $\alpha$-pinene) $\mathrm{O}$ atoms. While for simple cycloalkenes carbonyl termination products dominate (Tables 4-8), the major termination products of $\alpha$-pinene and 3-carene appear at the $m / z$ of the corresponding to hydroxy termination with nine $\mathrm{O}$ atoms (presumably four $\mathrm{OOH}$ groups), and $\alpha$-pinene also generates the next higher hydroxy termination product with $11 \mathrm{O}$ atoms (see Tables 12 and 13).

As already indicated for 4-methyl cyclohexene, which shows $\mathrm{HOM}$ with $11 \mathrm{O}$ atoms, $\mathrm{H}$ shift from tertiary $\mathrm{C}$ atoms can obviously lead to a spread of formation routes (tertiary $\mathrm{H}$ atoms shown in Fig. 6). So far, MT molecules are too complex to guess the pathways only from the observed mass spectra. However, the fact that the dominant MT termination products are hydroxy rather than carbonyl compounds indicates that alkoxy-involving steps may be more important for MT than for the simpler alkenes and that ring opening of the cyclobutyl/propyl rings is involved in HOM formation (Rissanen et al., 2015). A relative gain in hydroxy and hydroperoxy termination products is also commensurable with a higher number of peroxy radicals at tertiary $\mathrm{C}$ atoms, which cannot form ketones via $\mathrm{H}$-abstraction by air oxygen. Please note that although the oxidation degree is higher than to be expected from our formation scheme for plain $\mathrm{C}_{5}-\mathrm{C}_{7} \mathrm{cy}-$ cloalkenes, the mass spectrometric pattern of peroxy-radical with $m / z=m$, carbonyl $m-17$, hydroxy $m-15$, hydroperoxy $m+1$ still applies and helps to order the analysis of the mass spectra. We conclude that the routes to HOM for simple molecules proposed by us are basic but not sufficient to explain HOM formation in complex molecules.

\subsection{Dimers and peroxyradicals}

Besides $\mathrm{HOM}$ with the same number of $\mathrm{C}$ atoms as the precursor, we observe also HOM molecules with twice the $\mathrm{C}$ atom numbers of the precursors, thus having dimer character. Table 14 lists the detected and assigned HOM dimers from cyclopentene, which had the highest chemical turnover (due to the fastest rate coefficient and the largest $\mathrm{O}_{3}$ concentration). The peak intensities were normalized to the dominant dimer. The two most abundant dimers contain even number of $\mathrm{O}$ atoms and $14 \mathrm{H}$ atoms. But we found also dimers with $16 \mathrm{H}$ atoms and odd number of $\mathrm{O}$ atoms. The molecular compositions discussed here are not commensurable with peroxyhemiacetals (proposed by Tobias and Ziemann, 2000) which would have been formed by reaction of HOM peroxy radicals and HOM carbonyl compounds, and should have an odd number of $\mathrm{O}$ atoms but $14 \mathrm{H}$ atoms.

Since we observe the peroxy radicals directly, it is suggestive to test if the dimers are peroxides and arise from recombination of two peroxy radicals according to Reaction (R8) (Sequence 2). We assume that two peroxy radicals recombine to a peroxide under elimination of $\mathrm{O}_{2}$. Table 15 lists the dimers expected for cyclopentene by simply permuting all observed and some additional peroxy radicals (those with less O-substitution, which we expect but probably are not detectable for cyclopentene). The molecular formulas of dimers which were observed are marked in bold face. The most abundant, identified peroxy radicals (compare Table 4) are also marked in bold face.

The dimer with the largest signal has the molecular formula $\mathrm{C}_{10} \mathrm{H}_{14} \mathrm{O}_{14}$, and it can be formed by reaction of two $\mathrm{C}_{5} \mathrm{H}_{7} \mathrm{O}_{8}$, the dominant peroxy radical (cf. Table 4). But it is also clear that several combinations of peroxy radical pairs can lead to dimers with the same molecular mass. Formulas in Table 15 set in bold face and italic indicate dimers which involve the two most abundant peroxy radicals. We also detect dimers which comprise the involvement of low $\mathrm{O}$ precursors (Table 15 first line, normal face). This is indicative of their existence, although due to instrument limitations we probably are not able to detect them. Not all combinations are of the same likelihood. For example, $\mathrm{C}_{10} \mathrm{H}_{14} \mathrm{O}_{16}$ is less likely formed by dimerization of $\mathrm{C}_{5} \mathrm{H}_{7} \mathrm{O}_{9}$, which would arise from the minor hydroxy-peroxy path, but more likely by recombination of $\mathrm{C}_{5} \mathrm{H}_{7} \mathrm{O}_{8}$ and $\mathrm{C}_{5} \mathrm{H}_{7} \mathrm{O}_{10}$. Of course each combination of suited peroxy radical pairs may contribute somewhat to the observed dimer. The findings of $\mathrm{C}_{10} \mathrm{H}_{14} \mathrm{O}_{12,14,16}$ dimers in Table 14 mutually support our assignments of peroxy radicals as well as our assignments of dimers. It overall supports the basic formation schemes developed in Sect. 3.

Notably, there are still the two dimers in Table 14 with odd numbers of $\mathrm{O}$ atoms which contain $16 \mathrm{H}$ atoms. Due to the $16 \mathrm{H}$ atoms these dimers cannot be simply formed by any combination of the peroxy radicals detected during cyclopentene ozonolysis, which carry only seven $\mathrm{H}$ atoms. However, the $\mathrm{C}_{10} \mathrm{H}_{16} \mathrm{O}_{9}$ dimer may be formed as a re-combination of the most abundant $\mathrm{C}_{5} \mathrm{H}_{7} \mathrm{O}_{8}$ peroxy radical and a peroxy radical with the molecular formula $\mathrm{C}_{5} \mathrm{H}_{9} \mathrm{O}_{3}$. In the same way, $\mathrm{C}_{10} \mathrm{H}_{16} \mathrm{O}_{11}$ dimers could be formed by the observed $\mathrm{C}_{5} \mathrm{H}_{7} \mathrm{O}_{10}$ peroxy radical and the $\mathrm{C}_{5} \mathrm{H}_{9} \mathrm{O}_{3}$ peroxy radical. $\mathrm{C}_{5} \mathrm{H}_{9} \mathrm{O}_{3}$ is the molecular formula of the first peroxy radical in the oxidation chain of cyclopentene by $\mathrm{OH}$. Production of the $\mathrm{C}_{5} \mathrm{H}_{9} \mathrm{O}_{3}$ peroxy radical from cyclopentene occurs via $\mathrm{OH}$ addition to one site of the double bond and addition of $\mathrm{O}_{2}$ at the other site, which is an alkyl radical site. Reactions with $\mathrm{OH}$ are possible since we did not routinely quench dark $\mathrm{OH}$ in the ozonolysis experiments. 
Table 15. Possible dimers produced by permutations reactions of the monomer peroxy radicals of cyclopentene. Bold face: entities were detected. Italic: dimers were detected and arise from two most abundant peroxy radicals.

\begin{tabular}{|c|c|c|c|c|c|}
\hline & $\mathrm{C}_{5} \mathrm{H}_{7} \mathrm{O}_{6}$ & $\mathrm{C}_{5} \mathrm{H}_{7} \mathrm{O}_{7}$ & $\mathrm{C}_{5} \mathrm{H}_{7} \mathrm{O}_{8}$ & $\mathrm{C}_{5} \mathrm{H}_{7} \mathrm{O}_{9}$ & $\mathrm{C}_{5} \mathrm{H}_{7} \mathrm{O}_{10}$ \\
\hline $\begin{array}{l}\mathrm{C}_{5} \mathrm{H}_{7} \mathrm{O}_{6} \\
\mathrm{C}_{5} \mathrm{H}_{7} \mathrm{O}_{7} \\
\mathbf{C}_{\mathbf{5}} \mathbf{H}_{\mathbf{7}} \mathbf{O}_{\mathbf{8}} \\
\mathbf{C}_{\mathbf{5}} \mathbf{H}_{\mathbf{7}} \mathbf{O}_{\mathbf{9}} \\
\mathbf{C}_{\mathbf{5}} \mathbf{H}_{\mathbf{7}} \mathbf{O}_{\mathbf{1 0}}\end{array}$ & $\mathrm{C}_{10} \mathrm{H}_{14} \mathrm{O}_{10}$ & $\begin{array}{l}\mathrm{C}_{10} \mathrm{H}_{14} \mathrm{O}_{11} \\
\mathbf{C}_{\mathbf{1 0}} \mathbf{H}_{\mathbf{1 4}} \mathbf{O}_{12}\end{array}$ & $\begin{array}{l}\mathbf{C}_{\mathbf{1 0}} \mathbf{H}_{\mathbf{1 4}} \mathbf{O}_{\mathbf{1 2}} \\
\mathrm{C}_{10} \mathrm{H}_{14} \mathrm{O}_{13} \\
\boldsymbol{C}_{10} \boldsymbol{H}_{14} \boldsymbol{O}_{14}\end{array}$ & $\begin{array}{l}\mathrm{C}_{10} \mathrm{H}_{14} \mathrm{O}_{13} \\
\mathbf{C}_{\mathbf{1 0}} \mathbf{H}_{\mathbf{1 4}} \mathbf{O}_{\mathbf{1 4}} \\
\mathrm{C}_{10} \mathrm{H}_{14} \mathrm{O}_{15} \\
\mathbf{C}_{\mathbf{1 0}} \mathbf{H}_{\mathbf{1 4}} \mathbf{O}_{\mathbf{1 6}}\end{array}$ & $\begin{array}{l}\mathbf{C}_{\mathbf{1 0}} \mathbf{H}_{\mathbf{1 4}} \mathbf{O}_{\mathbf{1 4}} \\
\mathrm{C}_{10} \mathrm{H}_{14} \mathrm{O}_{15} \\
\boldsymbol{C}_{10} \boldsymbol{H}_{14} \boldsymbol{O}_{16} \\
\mathrm{C}_{10} \mathrm{H}_{14} \mathrm{O}_{17} \\
\mathrm{C}_{10} \mathrm{H}_{14} \mathrm{O}_{18}\end{array}$ \\
\hline
\end{tabular}

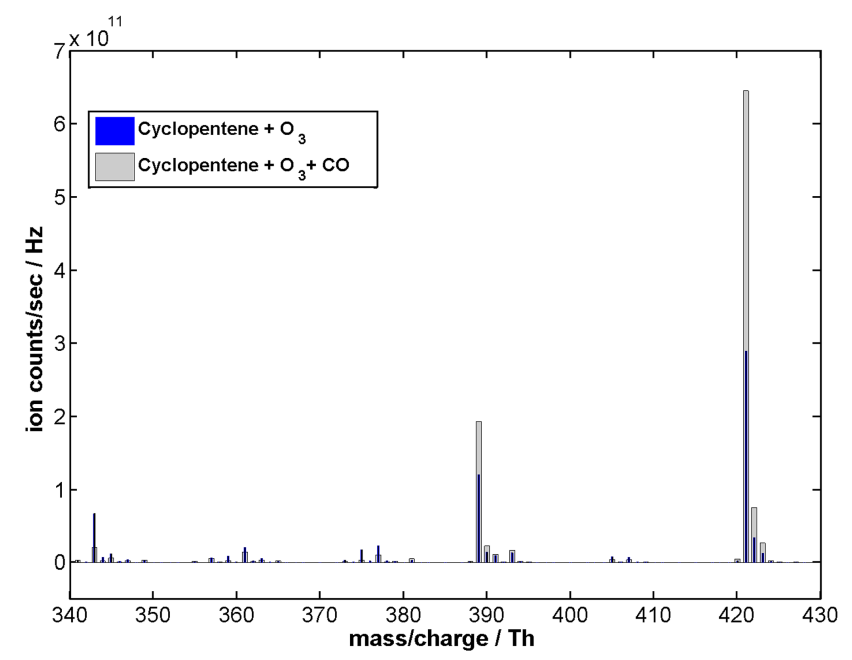

Figure 7. Comparison of the dimer HOM spectra resulting from ozonolysis of cyclopentene with $\mathrm{CO}$ addition (gray) and without $\mathrm{CO}$ addition (blue). The fraction of dimers which involve the $\mathrm{O}_{3}-$ peroxy radical from the addition of $\mathrm{OH}$ to the double bond of cyclopentene are reduced.

As first peroxy radical in the $\mathrm{OH}$-oxidation chain of cyclopentene, the $\mathrm{C}_{5} \mathrm{H}_{9} \mathrm{O}_{3}$ peroxy radical should be quite abundant. Due to the low number of $\mathrm{O}$ atoms in this radical it is not detectable with our APi-TOF-MS scheme. To test the hypothesis of $\mathrm{OH}$ reactions being involved in the formation of these dimers, $\mathrm{CO}$ was added as $\mathrm{OH}$ scavenger $(\sim 40 \mathrm{ppm})$ in a cyclopentene ozonolysis control experiment. Figure 7 shows the overlay of the dimer spectra from cyclopentene ozonolysis with and without $\mathrm{CO}$ addition.

$\mathrm{CO}$ addition indeed led to a decrease in the abundance of both $\mathrm{H}_{16}-\mathrm{HOM}$ dimers detected at 343 and $375 \mathrm{Th}$, suspected to arise from the $\mathrm{C}_{5} \mathrm{H}_{9} \mathrm{O}_{3}$ peroxy radical. Furthermore, the abundance of $\mathrm{C}_{10} \mathrm{H}_{14} \mathrm{O}_{12}$ (detected at $389 \mathrm{Th}$ ) and that of $\mathrm{C}_{10} \mathrm{H}_{14} \mathrm{O}_{14}$ (detected at $421 \mathrm{Th}$ ) increased. This is in accordance with suppression of the competition by $\mathrm{C}_{5} \mathrm{H}_{9} \mathrm{O}_{3}$ from cyclopentene $+\mathrm{OH}$ reaction. After suppression of $\mathrm{OH}$ more ozonolysis products in general and more dimers by ozonolysis-only products are formed, e.g., $\mathrm{C}_{5} \mathrm{H}_{7} \mathrm{O}_{8}+\mathrm{C}_{5} \mathrm{H}_{7} \mathrm{O}_{8}$.
Moreover, there are more peaks which decrease by $\mathrm{CO}$ addition. This means that these molecules likely involve oxidation by $\mathrm{OH}$ radicals at some step. It is noticeable that all peaks that decrease can be attributed to dimer structures containing an odd number of $\mathrm{O}$ atoms (the reagent ion ${ }^{15} \mathrm{NO}_{3}^{-}$ subtracted). In contrast, dimer structures that contain an even number of $\mathrm{O}$ atoms increase under $\mathrm{CO}$ addition, indicating that their formation involve ozonolysis-only products.

In the monomer region, the addition of $\mathrm{CO}$ should increase the relative contribution of hydroperoxide termination products since quenching with $\mathrm{CO}$ converts $\mathrm{OH}$ to $\mathrm{HO}_{2}$ molecules, thus increasing the $\mathrm{HO}_{2}$ concentration. Docherty et al. (2005) discussed such an effect of increasing $\mathrm{HO}_{2}$ concentration by scavenging $\mathrm{OH}$ in the dark on the formation of hydroperoxides (Reaction R4) in competition to dimer formation by $\mathrm{RO}_{2}+\mathrm{RO}_{2}$ reactions. This would be a further support of our assignment of peroxy radicals and their termination products but deserves more detailed investigation.

\subsection{Role of the hydroxy peroxy path}

As can be seen from the Tables 4-10,12, 13, peroxy radicals with even numbers of $\mathrm{O}$ atoms were often observed. In contrast, peroxy radicals with odd numbers of $\mathrm{O}$ atoms as well as their termination products were only rarely found. We hypothesize that peroxy radicals with odd numbers of $\mathrm{O}$ atoms can be formed from alkoxy radicals that undergo an H shift (Vereecken and Peeters, 2010), and thereby form the alkyl radical to which the $\mathrm{O}_{2}$ is added. Their low abundance can be understood applying basic steady-state considerations. $\mathrm{H}$ shifts of alkoxy radicals (Reaction R6c) formed in Reaction (R6a), and subsequent $\mathrm{O}_{2}$ addition (Reaction R6d), has to compete with the termination Reaction (R6b), if the alkoxy $\mathrm{C}$ atom carries an $\mathrm{H}$ atom. As $\mathrm{O}_{2}$ concentrations are very high, the chemical lifetime of an alkoxy radical is much shorter than that of a peroxy radical. This also presupposes that the consecutive addition of molecular oxygen after $\mathrm{H}$ shifts in peroxy radicals is highly efficient.

\section{Summary and conclusions}

A key to our analysis was the direct observation of highly oxidized peroxy radicals in oxidations initiated by ozone. As 
is expected in atmospheric oxidation processes, peroxy radicals were the pivotal point to elucidate the pathways of HOM formation and therewith the pathways to atmospherically relevant ELVOC. Peroxy radicals are formed in ozonolysis via the vinylhydroperoxide pathway, and are sequentially oxidized by rearrangement ( $\mathrm{H}$ shift) and subsequent addition of molecular oxygen, renewing the peroxy radical at the next level of oxidation (Ehn et al., 2014; Rissanen et al., 2014). Since only a single initial oxidation step by ozone is required and thereafter oxidation proceeds perpetuating a peroxy radical under addition of air oxygen alone, this process can be conceived as autoxidation of the peroxy radicals.

By our experimental studies of HOM formation using selected molecules with systematically varying structural properties, we deduced important steps on the route to HOM formation during ozonolysis. Peroxy radicals are formed via the vinylhydroperoxide path. Initially, aldehyde functionality facilitates the shift of an $\mathrm{H}$ atom from a $\mathrm{C}-\mathrm{H}$ bond to a peroxy radical group $>\mathrm{COO}^{\circ}$. As a consequence peroxy-carboxyl radicals are formed, which on further $\mathrm{H}$ shift reactions form percarboxylic acid groups. These are able to activate the $\mathrm{H}$ atoms on their neighbor $\alpha-\mathrm{C}$ atom. Thus, in the ozonolysis of simple endocyclic alkenes, up to $10 \mathrm{O}$ atoms can be incorporated in a peroxy radical, of those $6 \mathrm{O}$ atoms by the sequential autoxidation mechanism. We conclude that intermediates with two aldehyde end groups form di-percarboxylic acids with further carbonyl, hydroxy or hydroperoxide functionalities. We observed that presence of tertiary $\mathrm{H}$ atoms by methyl substitution or constraint ring structures, like for $\alpha$ pinene and $\Delta-3$-carene, leads to more options for the autoxidation mechanism to proceed. This is allowing for addition of more than six $\mathrm{O}$ atoms (here eight $\mathrm{O}$ atoms) and a widening of the termination product spectrum.

An aldehyde group at the $\omega$-end of the initial peroxy radical S2 favors the achievement of the highest oxidation degree. In the cases investigated here, methyl, hydroxy and keto groups are not efficient in promoting $\mathrm{H}$ shift of $\mathrm{C}-\mathrm{H}$ bonds at neighboring $\alpha-\mathrm{C}$ atoms to peroxy groups. The 1,4 $\mathrm{H}$ shift from the aldehyde group to the peroxy radical in those molecules (S5, S6, S7) may lead to a hydroperoxide, percarboxylic acid or hydroperoxy carboxylic acid, but then likely the autoxidation stops. If such molecules are formed, we may not be able to detect them with the $\mathrm{NO}_{3}^{-}$-APi-TOFMS. A key finding for the role of $\omega$-substitution is that (Z)6-nonenal is forming the same major HOM as cyclohexene (Rissanen et al., 2014).

In the first few steps, as long as $\mathrm{H}$ atoms susceptible to $\mathrm{H}$ shift are available, autoxidation can compete with the termination reactions. At later stages termination reactions become more important and carbonyl, hydroxy, and hydroperoxy termination products are formed in our NO poor system. Self-reactions of the HOM peroxy radicals lead to another class of dimer termination products, very likely peroxides. The elemental composition and relative abundance of the dimer structures indicate involvement of the monomer per- oxy radicals of all oxidation stages in their formation. The most abundant dimers always involve the most abundant peroxy radicals. In addition, we found dimers from the most abundant HOM peroxy radicals with the $\mathrm{O}_{3}$-peroxy radicals formed in the first step after attack addition of $\mathrm{OH}$ to the double bond. These disappeared when $\mathrm{OH}$ was quenched by $\mathrm{CO}$. In general, quenching with $\mathrm{CO}$ suppresses the $\mathrm{OH}$ pathways and shifts termination towards $\mathrm{HOO}$, as would be expected. Overall the mass spectrometric patterns of termination products and dimer formation support the pivotal role of highly oxidized peroxy radicals and that we indeed observe them directly.

We observe peroxy radicals with an odd number of oxygen; however, during ozonolysis their concentration were minor. The observations of peroxy radicals with an odd number of oxygen can be explained by the same concepts if we allow for a side pathway involving one intermediate step of alkoxy rearrangement $(\mathrm{H}$ shift in an alkoxy radical, thereby formation of an alkyl radical and $\mathrm{O}_{2}$ addition).

Considering the degree of oxidation as well as the functional groups in HOM, monomers and even more so dimers must have very low vapor pressures. Thus, HOM must play as ELVOC an important role in particle formation and SOA condensation (Ehn et al., 2014). The estimated molecular yields of ELVOC for $\alpha$-pinene of $7 \%$ (Ehn et al., 2014) and cyclcohexene of $4 \%$ (Rissanen et al., 2014) indicate that ELVOC formation is in any case a minor part from the viewpoint of gas-phase chemistry. However, considering molar yields of a few percent and the high degree of oxidation, a substantial part of atmospheric SOA mass should be formed from ELVOC. The organic fraction of particles at early stages of formation should consist nearly exclusively of ELVOC (Ehn et al., 2014).

Actually, in JPAC we earlier observed linear growth curves in SOA formation, which we did not understand at the time. A characteristic of those experiments was that particle formation was induced based on relatively low BVOC input and in presence of the BVOC-ozonolysis products (Mentel et al., 2009; Lang Yona et al., 2010). SOA growth curves of quasi non-volatile reaction products should be linear as Raoult's law does not apply, and everything condenses. (The SOA yield curves were still curved as there was a threshold before particle formation started (Mentel et al., 2009).)

An open question is the fate of HOM in the particulate phase. It seems obvious that the multifunctional HOM will not survive, but undergo condensation reactions. The products of those are probably not retrievable by thermoevaporation methods. It also raises the question how HOMbased SOA relates to the recently discussed glassy state of SOA particles (Koop et al., 2011; Shiraiwa et al., 2013; Virtanen et al., 2010; Zobrist et al., 2008).

We are confident that we deduced the main route of atmospheric oxidation that leads to "quasi" instantaneous formation of highly oxidized organic molecules. We are also confident that we deduced the major functionalization of HOM. 
Of course in our deductions there are still positive gaps (observations which we cannot explain with our current concepts) and negative gaps (missing structures that we would expect). But even at that level it is evident that formation of HOM is likely a general phenomenon, which was overlooked until very recently. To fully explore the general impact of HOM, we need also to understand the role of $\mathrm{OH}$ oxidation and how the chemical systems behave at reasonably high $\mathrm{NO}_{x}$ concentrations. CI-APi-TOF-MS constitutes an enormous progress as it allows for unambiguous determination of the molecular formulas of HOM in laboratory experiments. However, for detailed mechanism development one would need also structural information and quantification of (all) intermediates and products.

Acknowledgements. This work was supported by the EU-FP7 project PEGASOS (project no. 265148). M. Ehn was supported by the Emil Aaltonen foundation. T. Kurtén thanks the Academy of Finland for funding. Larger parts of this work were subject of the bachelor thesis (2013) of M. Springer. We would like to thank Gereon Elbers, FH Aachen (Jülich) for support and supervising the bachelor thesis of M. Springer.

The article processing charges for this open-access publication were covered by a Research

Centre of the Helmholtz Association.

Edited by: U. Baltensperger

\section{References}

Almeida, J., Schobesberger, S., Kuerten, A., Ortega, I. K., Kupiainen-Maatta, O., Praplan, A. P., Adamov, A., Amorim, A., Bianchi, F., Breitenlechner, M., David, A., Dommen, J., Donahue, N. M., Downard, A., Dunne, E., Duplissy, J., Ehrhart, S., Flagan, R. C., Franchin, A., Guida, R., Hakala, J., Hansel, A., Heinritzi, M., Henschel, H., Jokinen, T., Junninen, H., Kajos, M., Kangasluoma, J., Keskinen, H., Kupc, A., Kurten, T., Kvashin, A. N., Laaksonen, A., Lehtipalo, K., Leiminger, M., Leppa, J., Loukonen, V., Makhmutov, V., Mathot, S., McGrath, M. J., Nieminen, T., Olenius, T., Onnela, A., Petaja, T., Riccobono, F., Riipinen, I., Rissanen, M., Rondo, L., Ruuskanen, T., Santos, F. D., Sarnela, N., Schallhart, S., Schnitzhofer, R., Seinfeld, J. H., Simon, M., Sipilä, M., Stozhkov, Y., Stratmann, F., Tome, A., Troestl, J., Tsagkogeorgas, G., Vaattovaara, P., Viisanen, Y., Virtanen, A., Vrtala, A., Wagner, P. E., Weingartner, E., Wex, H., Williamson, C., Wimmer, D., Ye, P., Yli-Juuti, T., Carslaw, K. S., Kulmala, M., Curtius, J., Baltensperger, U., Worsnop, D. R., Vehkamaki, H., and Kirkby, J.: Molecular understanding of sulphuric acid-amine particle nucleation in the atmosphere, Nature, 502, 359-363, doi:10.1038/nature12663, 2013.

Berndt, T., Böge, O., Stratmann, F., Heintzenberg, J., and Kulmala, M.: Rapid formation of sulfuric acid particles at near-atmospheric conditions, Science, 307, 698-700, doi:10.1126/science.1104054, 2005.
Bzdek, B. R., Horan, A. J., Pennington, M. R., DePalma, J. W., Zhao, J., Jen, C. N., Hanson, D. R., Smith, J. N., McMurry, P. H., and Johnston, M. V.: Quantitative and time-resolved nanoparticle composition measurements during new particle formation, Farad. Discuss., 165, 25-43, doi:10.1039/c3fd00039g, 2013.

Cox, R. A. and Cole, J. A.: Chemical aspects of the autoignition of hydrocarbon-air mixtures, Combustion Flame, 60, 109-123, doi:10.1016/0010-2180(85)90001-x, 1985.

Crounse, J. D., Paulot, F., Kjaergaard, H. G., and Wennberg, P. O.: Peroxy radical isomerization in the oxidation of isoprene, Phys. Chem. Chem. Phys., 13, 13607-13613, doi:10.1039/c1cp21330j, 2011.

Crounse, J. D., Knap, H. C., Ornso, K. B., Jorgensen, S., Paulot, F., Kjaergaard, H. G., and Wennberg, P. O.: Atmospheric Fate of Methacrolein. 1. Peroxy Radical Isomerization Following Addition of $\mathrm{OH}$ and $\mathrm{O}_{2}$, J. Phys. Chem. A, 116, 5756-5762, doi:10.1021/jp211560u, 2012.

Crounse, J. D., Nielsen, L. B., Jorgensen, S., Kjaergaard, H. G., and Wennberg, P. O.: Autoxidation of Organic Compounds in the Atmosphere, J. Phys. Chem. Lett., 4, 3513-3520, doi:10.1021/jz4019207, 2013.

Docherty, K. S., Wu, W., Lim, Y. B., and Ziemann, P. J.: Contributions of organic peroxides to secondary aerosol formed from reactions of monoterpenes with O-3, Environ. Sci. Technol., 39, 4049-4059, doi:10.1021/es050228s, 2005.

Donahue, N. M., Kroll, J. H., Pandis, S. N., and Robinson, A. L.: A two-dimensional volatility basis set - Part 2: Diagnostics of organic-aerosol evolution, Atmos. Chem. Phys., 12, 615-634, doi:10.5194/acp-12-615-2012, 2012.

Ehn, M., Junninen, H., Petäjä, T., Kurtén, T., Kerminen, V.-M., Schobesberger, S., Manninen, H. E., Ortega, I. K., Vehkamäki, H., Kulmala, M., and Worsnop, D. R.: Composition and temporal behavior of ambient ions in the boreal forest, Atmos. Chem. Phys., 10, 8513-8530, doi:10.5194/acp-10-8513-2010, 2010.

Ehn, M., Kleist, E., Junninen, H., Petäjä, T., Lönn, G., Schobesberger, S., Dal Maso, M., Trimborn, A., Kulmala, M., Worsnop, D. R., Wahner, A., Wildt, J., and Mentel, Th. F.: Gas phase formation of extremely oxidized pinene reaction products in chamber and ambient air, Atmos. Chem. Phys., 12, 5113-5127, doi:10.5194/acp-12-5113-2012, 2012.

Ehn, M., Thornton, J. A., Kleist, E., Sipilä, M., Junninen, H., Pullinen, I., Springer, M., Rubach, F., Tillmann, R., Lee, B., LopezHilfiker, F., Andres, S., Acir, I.-H., Rissanen, M., Jokinen, T., Schobesberger, S., Kangasluoma, J., Kontkanen, J., Nieminen, T., Kurten, T., Nielsen, L. B., Jorgensen, S., Kjaergaard, H. G., Canagaratna, M., Maso, M. D., Berndt, T., Petaja, T., Wahner, A., Kerminen, V.-M., Kulmala, M., Worsnop, D. R., Wildt, J., and Mentel, T. F.: A large source of low-volatility secondary organic aerosol, Nature, 506, 476-479, doi:10.1038/nature13032, 2014.

Eisele, F. L. and Tanner, D. J.: Measurement of the gas-phase concentration of $\mathrm{H}_{2} \mathrm{SO}_{4}$ and Methane sulfonic acid and estimates of $\mathrm{H}_{2} \mathrm{SO}_{4}$ production and loss in the atmosphere, J. Geophys. Res.Atmos., 98, 9001-9010, doi:10.1029/93jd00031, 1993.

Finlayson-Pitts, B. J. and Pitts Jr., J. N.: Chemistry of the Upper and Lower Atmosphere, Academic Press, San Diego, 2000.

Glowacki, D. R. and Pilling, M. J.: Unimolecular Reactions of Peroxy Radicals in Atmospheric Chemistry and Combustion, Chem. 
Phys. Chem., 11, 3836-3843, doi:10.1002/cphc.201000469, 2010.

Hamed, A., Joutsensaari, J., Mikkonen, S., Sogacheva, L., Dal Maso, M., Kulmala, M., Cavalli, F., Fuzzi, S., Facchini, M. C., Decesari, S., Mircea, M., Lehtinen, K. E. J., and Laaksonen, A.: Nucleation and growth of new particles in Po Valley, Italy, Atmos. Chem. Phys., 7, 355-376, doi:10.5194/acp-7-355-2007, 2007.

Heiden, A. C., Kobel, K., Langebartels, C., Schuh-Thomas, G., and Wildt, J.: Emissions of oxygenated volatile organic compounds from plants - part I: Emissions from lipoxygenase activity, J. Atmos. Chem., 45, 143-172, doi:10.1023/a:1024069605420, 2003.

Jimenez, J. L., Canagaratna, M. R., Donahue, N. M., Prevot, A. S. H., Zhang, Q., Kroll, J. H., DeCarlo, P. F., Allan, J. D., Coe, H., Ng, N. L., Aiken, A. C., Docherty, K. S., Ulbrich, I. M., Grieshop, A. P., Robinson, A. L., Duplissy, J., Smith, J. D., Wilson, K. R., Lanz, V. A., Hueglin, C., Sun, Y. L., Tian, J., Laaksonen, A., Raatikainen, T., Rautiainen, J., Vaattovaara, P., Ehn, M., Kulmala, M., Tomlinson, J. M., Collins, D. R., Cubison, M. J., Dunlea, E. J., Huffman, J. A., Onasch, T. B., Alfarra, M. R., Williams, P. I., Bower, K., Kondo, Y., Schneider, J., Drewnick, F., Borrmann, S., Weimer, S., Demerjian, K., Salcedo, D., Cottrell, L., Griffin, R., Takami, A., Miyoshi, T., Hatakeyama, S., Shimono, A., Sun, J. Y., Zhang, Y. M., Dzepina, K., Kimmel, J. R., Sueper, D., Jayne, J. T., Herndon, S. C., Trimborn, A. M., Williams, L. R., Wood, E. C., Middlebrook, A. M., Kolb, C. E., Baltensperger, U., and Worsnop, D. R.: Evolution of Organic Aerosols in the Atmosphere, Science, 326, 1525-1529, doi:10.1126/science.1180353, 2009.

Johnson, D. and Marston, G.: The gas-phase ozonolysis of unsaturated volatile organic compounds in the troposphere, Chem. Soc. Rev., 37, 699-716, doi:10.1039/b704260b, 2008.

Jokinen, T., Sipilä, M., Junninen, H., Ehn, M., Lönn, G., Hakala, J., Petäjä, T., Mauldin III, R. L., Kulmala, M., and Worsnop, D. R.: Atmospheric sulphuric acid and neutral cluster measurements using CI-APi-TOF, Atmos. Chem. Phys., 12, 4117-4125, doi:10.5194/acp-12-4117-2012, 2012.

Jokinen, T., Sipilä, M., Richters, S., Kerminen, V.-M., Paasonen, P., Stratmann, F., Worsnop, D., Kulmala, M., Ehn, M., Herrmann, H., and Berndt, T.: Rapid Autoxidation Forms Highly Oxidized RO2 Radicals in the Atmosphere, Angwe. Chem. Internat. Ed., 53, 14596-14600, doi:10.1002/anie.201408566, 2014.

Jorand, F., Heiss, A., Perrin, O., Sahetchian, K., Kerhoas, L., and Einhorn, J.: Isomeric hexyl-ketohydroperoxides formed by reactions of hexoxy and hexylperoxy radicals in oxygen, Int. J. Chem. Kin., 35, 354-366, doi:10.1002/kin.10136, 2003.

Junninen, H., Ehn, M., Petäjä, T., Luosujärvi, L., Kotiaho, T., Kostiainen, R., Rohner, U., Gonin, M., Fuhrer, K., Kulmala, M., and Worsnop, D. R.: A high-resolution mass spectrometer to measure atmospheric ion composition, Atmos. Meas. Tech., 3, 10391053, doi:10.5194/amt-3-1039-2010, 2010.

Kerminen, V. M., Lihavainen, H., Komppula, M., Viisanen, Y., and Kulmala, M.: Direct observational evidence linking atmospheric aerosol formation and cloud droplet activation, Geophys. Res. Lett., 32, L14803, doi:14810.11029/2005GL023130, 2005.

Kerminen, V.-M., Petäjä, T., Manninen, H. E., Paasonen, P., Nieminen, T., Sipilä, M., Junninen, H., Ehn, M., Gagné, S., Laakso, L., Riipinen, I., Vehkamäki, H., Kurten, T., Ortega, I. K., Dal Maso, M., Brus, D., Hyvärinen, A., Lihavainen, H., Leppä, J.,
Lehtinen, K. E. J., Mirme, A., Mirme, S., Hõrrak, U., Berndt, T., Stratmann, F., Birmili, W., Wiedensohler, A., Metzger, A., Dommen, J., Baltensperger, U., Kiendler-Scharr, A., Mentel, T. F., Wildt, J., Winkler, P. M., Wagner, P. E., Petzold, A., Minikin, A., Plass-Dülmer, C., Pöschl, U., Laaksonen, A., and Kulmala, M.: Atmospheric nucleation: highlights of the EUCAARI project and future directions, Atmos. Chem. Phys., 10, 10829-10848, doi:10.5194/acp-10-10829-2010, 2010.

Kirkby, J., Curtius, J., Almeida, J., Dunne, E., Duplissy, J., Ehrhart, S., Franchin, A., Gagne, S., Ickes, L., Kurten, A., Kupc, A., Metzger, A., Riccobono, F., Rondo, L., Schobesberger, S., Tsagkogeorgas, G., Wimmer, D., Amorim, A., Bianchi, F., Breitenlechner, M., David, A., Dommen, J., Downard, A., Ehn, M., Flagan, R. C., Haider, S., Hansel, A., Hauser, D., Jud, W., Junninen, H., Kreissl, F., Kvashin, A., Laaksonen, A., Lehtipalo, K., Lima, J., Lovejoy, E. R., Makhmutov, V., Mathot, S., Mikkila, J., Minginette, P., Mogo, S., Nieminen, T., Onnela, A., Pereira, P., Petaja, T., Schnitzhofer, R., Seinfeld, J. H., Sipilä, M., Stozhkov, Y., Stratmann, F., Tome, A., Vanhanen, J., Viisanen, Y., Vrtala, A., Wagner, P. E., Walther, H., Weingartner, E., Wex, H., Winkler, P. M., Carslaw, K. S., Worsnop, D. R., Baltensperger, U., and Kulmala, M.: Role of sulphuric acid, ammonia and galactic cosmic rays in atmospheric aerosol nucleation, Nature, 476, 429-433, doi:10.1038/nature10343, 2011.

Koop, T., Bookhold, J., Shiraiwa, M., and Poeschl, U.: Glass transition and phase state of organic compounds: dependency on molecular properties and implications for secondary organic aerosols in the atmosphere, Phys. Chem. Chem. Phys., 13, 19238-19255, doi:10.1039/c1cp22617g, 2011.

Kuang, C., McMurry, P. H., McCormick, A. V., and Eisele, F. L.: Dependence of nucleation rates on sulfuric acid vapor concentration in diverse atmospheric locations, J. Geophys. Res.-Atmos., 113, D10209, doi:10.1029/2007jd009253, 2008.

Kuang, C., McMurry, P. H., and McCormick, A. V.: Determination of cloud condensation nuclei production from measured new particle formation events, Geophys. Res. Lett., 36, L09822, doi:10.1029/2009g1037584, 2009.

Kulmala, M., Kontkanen, J., Junninen, H., Lehtipalo, K., Manninen, H. E., Nieminen, T., Petaja, T., Sipilä, M., Schobesberger, S., Rantala, P., Franchin, A., Jokinen, T., Jarvinen, E., Aijala, M., Kangasluoma, J., Hakala, J., Aalto, P. P., Paasonen, P., Mikkila, J., Vanhanen, J., Aalto, J., Hakola, H., Makkonen, U., Ruuskanen, T., Mauldin, R. L., Duplissy, J., Vehkamaki, H., Back, J., Kortelainen, A., Riipinen, I., Kurten, T., Johnston, M. V., Smith, J. N., Ehn, M., Mentel, T. F., Lehtinen, K. E. J., Laaksonen, A., Kerminen, V. M., and Worsnop, D. R.: Direct Observations of Atmospheric Aerosol Nucleation, Science, 339, 943 946, doi:10.1126/science.1227385, 2013.

Kulmala, M., Kerminen, V. M., Anttila, T., Laaksonen, A., and O'Dowd, C. D.: Organic aerosol formation via sulphate cluster activation, J. Geophys. Res.-Atmos., 109, D04205, doi:10.1029/2003jd003961, 2004a.

Kulmala, M., Vehkamaki, H., Petajda, T., Dal Maso, M., Lauri, A., Kerminen, V. M., Birmili, W., and McMurry, P. H.: Formation and growth rates of ultrafine atmospheric particles: a review of observations, J. Aerosol Sci., 35, 143-176, 2004 b.

Lang-Yona, N., Rudich, Y., Mentel, Th. F., Bohne, A., Buchholz, A., Kiendler-Scharr, A., Kleist, E., Spindler, C., Tillmann, R., and Wildt, J.: The chemical and microphysical properties of 
secondary organic aerosols from Holm Oak emissions, Atmos. Chem. Phys., 10, 7253-7265, doi:10.5194/acp-10-7253-2010, 2010.

Mentel, Th. F., Wildt, J., Kiendler-Scharr, A., Kleist, E., Tillmann, R., Dal Maso, M., Fisseha, R., Hohaus, Th., Spahn, H., Uerlings, R., Wegener, R., Griffiths, P. T., Dinar, E., Rudich, Y., and Wahner, A.: Photochemical production of aerosols from real plant emissions, Atmos. Chem. Phys., 9, 4387-4406, doi:10.5194/acp9-4387-2009, 2009.

Metzger, A., Verheggen, B., Dommen, J., Duplissy, J., Prevot, A. S. H., Weingartner, E., Riipinen, I., Kulmala, M., Spracklen, D. V., Carslaw, K. S., and Baltensperger, U.: Evidence for the role of organics in aerosol particle formation under atmospheric conditions, Proc. Natl. Acad. Sci. USA, 107, 6646-6651, doi:10.1073/Proc. Natl. Acad. Sci. USA.0911330107, 2010.

Murphy, B. N., Donahue, N. M., Robinson, A. L., and Pandis, S. N.: A naming convention for atmospheric organic aerosol, Atmos. Chem. Phys., 14, 5825-5839, doi:10.5194/acp-14-58252014, 2014.

Nguyen, T. L., Vereecken, L., and Peeters, J.: HOx Regeneration in the Oxidation of Isoprene III: Theoretical Study of the key Isomerisation of the Z-delta-hydroxyperoxy Isoprene Radicals, Chem. Phys. Chem., 11, 3996-4001, doi:10.1002/cphc.201000480, 2010.

Paasonen, P., Nieminen, T., Asmi, E., Manninen, H. E., Petäjä, T., Plass-Dülmer, C., Flentje, H., Birmili, W., Wiedensohler, A., Hõrrak, U., Metzger, A., Hamed, A., Laaksonen, A., Facchini, M. C., Kerminen, V.-M., and Kulmala, M.: On the roles of sulphuric acid and low-volatility organic vapours in the initial steps of atmospheric new particle formation, Atmos. Chem. Phys., 10, 11223-11242, doi:10.5194/acp-10-11223-2010, 2010.

Peeters, J., Nguyen, T. L., and Vereecken, L.: HOx radical regeneration in the oxidation of isoprene, Phys. Chem. Chem. Phys., 11, 5935-5939, 10.1039/b908511d, 2009.

Perrin, O., Heiss, A., Sahetchian, K., Kerhoas, L., and Einhorn, J.: Determination of the isomerization rate constant $\mathrm{HOCH}_{2} \mathrm{CH}_{2} \mathrm{CH}_{2} \mathrm{CH}(\mathrm{OO} \cdot) \mathrm{CH}_{3} \rightarrow$ $\left(\mathrm{HOC} \cdot \mathrm{HCH}_{2} \mathrm{CH}_{2} \mathrm{CH}(\mathrm{OOH}) \mathrm{CH}_{3}\right.$. Importance of intramolecular hydroperoxy isomerization in tropospheric chemistry, Int. J. Chem. Kin., 30, 875-887, doi:10.1002/(sici)10974601(1998)30:12<875::aid-kin2>3.0.co;2-8, 1998.

Praplan, A. P., Barmet, P., Dommen, J., and Baltensperger, U.: Cyclobutyl methyl ketone as a model compound for pinonic acid to elucidate oxidation mechanisms, Atmos. Chem. Phys., 12, 10749-10758, doi:10.5194/acp-12-10749-2012, 2012.

Riccobono, F., Rondo, L., Sipilä, M., Barmet, P., Curtius, J., Dommen, J., Ehn, M., Ehrhart, S., Kulmala, M., Kürten, A., Mikkilä, J., Paasonen, P., Petäjä, T., Weingartner, E., and Baltensperger, U.: Contribution of sulfuric acid and oxidized organic compounds to particle formation and growth, Atmos. Chem. Phys., 12, 9427-9439, doi:10.5194/acp-12-9427-2012, 2012.

Riccobono, F., Schobesberger, S., Scott, C. E., Dommen, J., Ortega, I. K., Rondo, L., Almeida, J., Amorim, A., Bianchi, F., Breitenlechner, M., David, A., Downard, A., Dunne, E. M., Duplissy, J., Ehrhart, S., Flagan, R. C., Franchin, A., Hansel, A., Junninen, H., Kajos, M., Keskinen, H., Kupc, A., Kuerten, A., Kvashin, A. N., Laaksonen, A., Lehtipalo, K., Makhmutov, V., Mathot, S., Nieminen, T., Onnela, A., Petaja, T., Praplan, A. P., Santos, F. D., Schallhart, S., Seinfeld, J. H., Sipilä, M., Spracklen, D.
V., Stozhkov, Y., Stratmann, F., Tome, A., Tsagkogeorgas, G., Vaattovaara, P., Viisanen, Y., Vrtala, A., Wagner, P. E., Weingartner, E., Wex, H., Wimmer, D., Carslaw, K. S., Curtius, J., Donahue, N. M., Kirkby, J., Kulmala, M., Worsnop, D. R., and Baltensperger, U.: Oxidation Products of Biogenic Emissions Contribute to Nucleation of Atmospheric Particles, Science, 344, 717-721, doi:10.1126/science.1243527, 2014.

Riipinen, I., Pierce, J. R., Yli-Juuti, T., Nieminen, T., Häkkinen, S., Ehn, M., Junninen, H., Lehtipalo, K., Petäjä, T., Slowik, J., Chang, R., Shantz, N. C., Abbatt, J., Leaitch, W. R., Kerminen, V.-M., Worsnop, D. R., Pandis, S. N., Donahue, N. M., and Kulmala, M.: Organic condensation: a vital link connecting aerosol formation to cloud condensation nuclei $(\mathrm{CCN})$ concentrations, Atmos. Chem. Phys., 11, 3865-3878, doi:10.5194/acp-11-38652011, 2011.

Riipinen, I., Yli-Juuti, T., Pierce, J. R., Petaja, T., Worsnop, D. R., Kulmala, M., and Donahue, N. M.: The contribution of organics to atmospheric nanoparticle growth, Nature Geosci., 5, 453-458, doi:10.1038/ngeo1499, 2012.

Rissanen, M. P., Kurtén, T., Sipilä, M., Thornton, J. A., Kangasluoma, J., Sarnela, N., Junninen, H., Jørgensen, S., Schallhart, S., Kajos, M. K., Taipale, R., Springer, M., Mentel, T. F., Ruuskanen, T., Petäjä, T., Worsnop, D. R., Kjaergaard, H. G., and Ehn, M.: The Formation of Highly Oxidized Multifunctional Products in the Ozonolysis of Cyclohexene, J. Am. Chem. Soc., 136 15596-15606, doi:10.1021/ja507146s, 2014.

Rissanen, M. P., Kurten, T., Sipila, M., Thornton, J. A., Kausiala, O., Garmash, O., Kjaergaard, H. G., Petaja, T., Worsnop, D. R., Ehn, M., and Kulmala, M.: Effects of Chemical Complexity on the Autoxidation Mechanisms of Endocyclic Alkene Ozonolysis Products: From Methylcyclohexenes toward Understanding alpha-Pinene, J. Phys. Chem. A, 119, 4633-4650, 2015.

Schobesberger, S., Junninen, H., Bianchi, F., Lonn, G., Ehn, M., Lehtipalo, K., Dommen, J., Ehrhart, S., Ortega, I. K., Franchin, A., Nieminen, T., Riccobono, F., Hutterli, M., Duplissy, J., Almeida, J., Amorim, A., Breitenlechner, M., Downard, A. J., Dunne, E. M., Flagan, R. C., Kajos, M., Keskinen, H., Kirkby, J., Kupc, A., Kuerten, A., Kurten, T., Laaksonen, A., Mathot, S., Onnela, A., Praplan, A. P., Rondo, L., Santos, F. D., Schallhart, S., Schnitzhofer, R., Sipilä, M., Tome, A., Tsagkogeorgas, G., Vehkamaki, H., Wimmer, D., Baltensperger, U., Carslaw, K. S., Curtius, J., Hansel, A., Petaja, T., Kulmala, M., Donahue, N. M., and Worsnop, D. R.: Molecular understanding of atmospheric particle formation from sulfuric acid and large oxidized organic molecules, Proc. Natl. Acad. Sci. USA, 110, 1722317228, doi:10.1073/Proc. Natl. Acad. Sci. USA.1306973110, 2013.

Shiraiwa, M., Zuend, A., Bertram, A. K., and Seinfeld, J. H.: Gasparticle partitioning of atmospheric aerosols: interplay of physical state, non-ideal mixing and morphology, Phys. Chem. Chem. Phys., 15, 11441-11453, doi:10.1039/c3cp51595h, 2013.

Sipilä, M., Berndt, T., Petaja, T., Brus, D., Vanhanen, J., Stratmann, F., Patokoski, J., Mauldin, R. L., III, Hyvarinen, A.-P., Lihavainen, H., and Kulmala, M.: The Role of Sulfuric Acid in Atmospheric Nucleation, Science, 327, 1243-1246, 10.1126/science.1180315, 2010.

Spracklen, D. V., Carslaw, K. S., Merikanto, J., Mann, G. W., Reddington, C. L., Pickering, S., Ogren, J. A., Andrews, E., Baltensperger, U., Weingartner, E., Boy, M., Kulmala, M., Laakso, 
L., Lihavainen, H., Kivekäs, N., Komppula, M., Mihalopoulos, N., Kouvarakis, G., Jennings, S. G., O’Dowd, C., Birmili, W., Wiedensohler, A., Weller, R., Gras, J., Laj, P., Sellegri, K., Bonn, B., Krejci, R., Laaksonen, A., Hamed, A., Minikin, A., Harrison, R. M., Talbot, R., and Sun, J.: Explaining global surface aerosol number concentrations in terms of primary emissions and particle formation, Atmos. Chem. Phys., 10, 4775-4793, doi:10.5194/acp-10-4775-2010, 2010.

Tobias, H. J. and Ziemann, P. J.: Thermal desorption mass spectrometric analysis of organic aerosol formed from reactions of 1-tetradecene and $\mathrm{O}_{3}$ in the presence of alcohols and carboxylic acids, Environ. Sci. Technol., 34, 2105-2115, doi:10.1021/es9907156, 2000.

Vereecken, L. and Francisco, J. S.: Theoretical studies of atmospheric reaction mechanisms in the troposphere, Chemical Soc. Rev., 41, 6259-6293, doi:10.1039/c2cs35070j, 2012.

Vereecken, L. and Peeters, J.: A structure-activity relationship for the rate coefficient of H-migration in substituted alkoxy radicals, Phys. Chem. Chem. Phys., 12, 12608-12620, doi:10.1039/c0cp00387e, 2010.

Vereecken, L., Mueller, J. F., and Peeters, J.: Low-volatility poly-oxygenates in the $\mathrm{OH}$-initiated atmospheric oxidation of alpha-pinene: impact of non-traditional peroxyl radical chemistry, Phys. Chem. Chem. Phys., 9, 5241-5248, doi:10.1039/b708023a, 2007.

Virtanen, A., Joutsensaari, J., Koop, T., Kannosto, J., Yli-Pirila, P., Leskinen, J., Makela, J. M., Holopainen, J. K., Poeschl, U., Kulmala, M., Worsnop, D. R., and Laaksonen, A.: An amorphous solid state of biogenic secondary organic aerosol particles, Nature, 467, 824-827, doi:10.1038/nature09455, 2010.
Vuollekoski, H., Nieminen, T., Paasonen, P., Sihto, S.-L., Boy, M., Manninen, H., Lehtinen, K., Kerminen, V.-M., and Kulmala, M.: Atmospheric nucleation and initial steps of particle growth: $\mathrm{Nu}-$ merical comparison of different theories and hypotheses, Atmos. Res., 98, 229-236, doi:10.1016/j.atmosres.2010.04.007, 2010.

Yli-Juuti, T., Nieminen, T., Hirsikko, A., Aalto, P. P., Asmi, E., Hõrrak, U., Manninen, H. E., Patokoski, J., Dal Maso, M., Petäjä, T., Rinne, J., Kulmala, M., and Riipinen, I.: Growth rates of nucleation mode particles in Hyytiälä during 20032009: variation with particle size, season, data analysis method and ambient conditions, Atmos. Chem. Phys., 11, 12865-12886, doi:10.5194/acp-11-12865-2011, 2011.

Zhang, R. Y., Suh, I., Zhao, J., Zhang, D., Fortner, E. C., Tie, X. X., Molina, L. T., and Molina, M. J.: Atmospheric new particle formation enhanced by organic acids, Science, 304, 1487-1490, doi:10.1126/science.1095139, 2004.

Zhao, J., Smith, J. N., Eisele, F. L., Chen, M., Kuang, C., and McMurry, P. H.: Observation of neutral sulfuric acid-amine containing clusters in laboratory and ambient measurements, Atmos. Chem. Phys., 11, 10823-10836, doi:10.5194/acp-1110823-2011, 2011.

Zobrist, B., Marcolli, C., Pedernera, D. A., and Koop, T.: Do atmospheric aerosols form glasses?, Atmos. Chem. Phys., 8, 52215244, doi:10.5194/acp-8-5221-2008, 2008. 